\title{
E1 parlamento de Juan II ante las cortes generales de Monzón (1469). Una pequeña crónica autobiográfica en lengua castellanoaragonesa
}

\author{
The parlament of Juan II ante the general Courts in (1469). Al little \\ autobiographic cronicle in castilian-aragonese lenguage \\ DAVID GUIXERAS \\ Agustín Rubio Vela \\ daguixeras@gmail.com \\ rubiovela@yahoo.es
}

I. $S$.

\begin{abstract}
Resumen: Edición crítica y estudio histórico, formal y lingüístico del discurso con el que Juan II de Aragón abrió, el 13 de noviembre de 1469, las cortes generales de Monzón. En plena guerra civil catalana, los rebeldes habían ofrecido la corona a Renato de Anjou, y la llegada desde Francia de su hijo, el duque de Lorena, con un poderoso ejército obligaba a pedir subsidios para afrontar la grave situación. En este parlamento, una de las escasas muestras de aragonés tardío conservadas, el monarca hizo un relato autobiográfico de su reinado de innegable sesgo maniqueo.
\end{abstract}

Palabras clave: Juan II de Aragón, oratoria parlamentaria, Corona de Aragón, cortes generales, siglo XV, guerra civil catalana, lengua aragonesa

\begin{abstract}
This article contains the critical edition and study (history, form and language) of John II of Aragon's opening speech, which took place at the general court in Monzón on 13th November 1469. At the height of Catalan Civil War, the rebels had offered the crown to Renato of Anjou. However, his son's arrival, the duke of Lorena, from France with a powerful army forced the king to ask for benefits in order to face up to the grave situation. In this discourse, one of the few remaining samples of the late Aragonese language, the king produced an autobiographical account of his reign with an undeniable manichaen guidance.
\end{abstract}

Keywords: Juan II of Aragon, parlamentari oratory, Crown of Aragon, General Courts, !5th. century, Catalan Civil War, aragonese language 
David Guixeras \& Agustín Rubio Vela. El parlamento de Juan II ante las cortes generales de Monzón (1469). Una pequeña crónica autobiográfica en lengua castellanoaragonesa

El 5 de septiembre de 1469, desde el Vendrell, Juan II de Aragón convocó a sus reinos a cortes generales para el 15 de octubre en la villa de Monzón, «por la defensa dellos», en palabras de Jerónimo Zurita, con el objetivo concreto de «echar de su señorío al duque Reyner y al duque de Lorena, su hijo, que con gran poder de armas del reino de Francia se esforzaban de invadir y ocupar sus tierras, y para tratar de reducir a su obediencia y fidelidad los que tan malvadamente habían conspirado contra su rey y señor natural y permanecían en su dureza». Era, pues, la guerra civil catalana el motivo de la convocatoria, a la que habrían de asistir representantes de Aragón, de Valencia, de Mallorca y de aquellos territorios del principado que no se encontraban en manos de los rebeldes. Éstos habían ofrecido la corona a Renato de Anjou, y la llegada desde Francia de su hijo, el duque de Lorena, con un importante ejército reactivaba el conflicto y obligaba a Juan II a tomar medidas para afrontar la grave situación económica y militar «en tiempo de tan extremada falta de dinero, y hallándose tan gran parte del principado en poder de rebeldes y de los enemigos» (Zurita: XVIII, VII y XXIX).

La asamblea no se reunió en la fecha prevista, sino algo más tarde. Tras sucesivas prórrogas, las sesiones comenzaron el 13 de noviembre de 1469, con la propuesta inaugural del rey, según reza en las páginas preliminares de uno de los procesos llegados hasta nosotros:

\begin{abstract}
Preterea die lune desuper assignata qua conputabatur tertia decima die mensis novembris, convocada e ajustada la dita cort, la dia ja tarda, ab so de anafil e trompeta per la dita vila de Monçó e llochs acostumats de aquella, ab crida pública, per lo trompeta de la dita vila e no-res-menys a so de campana ut moris est, en la dita ecclésia de nostre dona Santa Maria, constituit lo molt alt e molt excel lent senyor lo senyor don Johan, rey de Aragó, seÿt sobre lo cadafal en una cadira real molt ornadament, ab alta e intel ligible veu davant gran multitut de pobles féu la proposició del tenor següent $\left[\ldots . .{ }^{1}\right.$
\end{abstract}

En efecto, ese día de mediados de noviembre dieron comienzo las cortes generales, a cuyo discurso inaugural, pieza oratoria no ignorada por los historiadores, aunque no siempre correctamente datada, ${ }^{2}$ están dedicadas las páginas que siguen. El soberano, solemnemente sentado en el trono, se dirigió a sus súbditos aragoneses, catalanes, mallorquines y valencianos, no en catalán, como era costumbre de sus predecesores de la casa de Barcelona, sino, como ya hiciera en 1416 su hermano Alfonso el Magnánimo, en la lengua de los aragoneses; ${ }^{3}$ una lengua en avanzado grado de

1 Archivo Municipal de Valencia [AMV], Processos de corts, yy-24 ("Procés del braç real e actes en aquell fets axí particulars del braç real com dels altres braços fets en la cort de Monçó»), f. 5v.

2 Es equivocada la datación de Calmette (1903: 304), que lo sitúa el 10 de abril de 1470: «Jean II réunit, à Monzon, le 10 avril, des Cortes où siegèrent des délegués de toutes les villes soumises a l’obédience royale». El error cronológico pasó a Vicens Vives: «mandó convocar Cortes generales en la villa de Monzón, las cuales, después de varias prórrogas, se inauguraron el 10 de abril de 1470» (2003: 336). Sí dan la fecha correcta: Coroleu e Inglada, y Pella y Forgas (1876: 297): "por fin se reunieron el dia 13 de Noviembre á las cinco de la tarde en la iglesia de Santa Maria»; Martínez Aloy (1930: 246): «...y aunque el Monarca en su discurso de 13 de noviembre procuró hacer manifestaciones claras de respeto a nuestros fueros...»; así como Canellas (Menéndez Pidal 1982: 454); y Ryder (2007: 202) .

3 A partir de 1412, con la llegada de la nueva dinastía, la lengua familiar de los reyes de la Corona de Aragón dejó de ser el catalán. El estatus lingüístico precedente se mantuvo en la cancillería, y los documentos en vulgar siguieron siendo 
David Guixeras \& Agustín Rubio Vela. El parlamento de Juan II ante las cortes generales de Monzón (1469). Una pequeña crónica autobiográfica en lengua castellanoaragonesa

castellanización en la segunda mitad del siglo XV, pero que no era el castellano del reino de Castilla, idioma familiar de los Trastámara; de ahí que, para adjetivarla, los filólogos hayan recurrido a una voz doble: aragonesacastellana o castellano-aragonesa. ${ }^{4}$

En su clásica obra sobre las cortes catalanas, Coroleu e Inglada y Pella y Forgas (1876: 297-299) resumieron el contenido de aquel discurso de apertura en el que «manifestó el Rey á la asamblea la apurada situación en que se encontraba», y publicaron seis largos párrafos. Pero fue Joseph Calmette quien, varias décadas después, llamó la atención acerca del interés de ese largo parlamento, «enérgico y hábil», escrito «en langue castillane», que dio a conocer íntegramente, traducido al francés, en su importante estudio sobre la revolución catalana, donde, en notas a pie de página, reprodujo cinco breves fragmentos del original (Calmette 1903: 304-313). El monarca habría esbozado ante las cortes, según el historiador galo, una verdadera historia apologética de su propio reinado, convenientemente centrada en acontecimientos de los once años transcurridos desde su llegada al trono en 1458. Habría sido una intervención sesgada, pero brillante, magistral y eficaz, con la cual impresionó vivamente a los representantes de los reinos, que acabaron votando considerables subsidios. ${ }^{5}$

Vicens Vives, en su estudio sobre Juan II, hizo igualmente una valoración extraordinariamente positiva de la disertación real, a la que se refirió como «uno de los más hábiles discursos que jamás ha pronunciado un político», y resumió así: «Después de hacer historia del desencadenamiento del conflicto en Cataluña, que según él habían provocado los jefes de los rebeldes con el único propósito de usurparle el señorío sobre el Principado, Juan II extendía su mirada sobre los desastres

redactados en catalán o en aragonés según fueran dirigidos a personas, poblaciones o instituciones de territorios de una u otra lengua. El problema de la dualidad lingüística de los territorios ibéricos se había de plantear en las cortes generales conjuntas, «no tant com a conflicte d’intel lecció sinó com a reivindicació dels drets de cada territori». Fue afrontado por los monarcas de la dinastía barcelonesa de manera equilibrada: en las cortes de Monzón de 1362-1363 y de 1382-1383 se procuró utilizar ambas lenguas, catalán y aragonés. Décadas más tarde, cuando el Magnánimo se dirigió en castellano a las cortes de Barcelona en 1416, su actitud fue «censurada per les ciutats de Barcelona, València $i$ Saragossa», no tanto por el uso de esa lengua como por «la vulneració dels usos lingüístics que avui en diríem 'oficials' dels diferents estats de la Corona d’Aragó» (Rodrigo Lizondo 2013: 29-30). Vid. también Cawsey (2008: 183).

4 Coloma Lleal (1997: 8) escribe que, en la Corona de Aragón, «una parte no desdeñable de la correspondencia real» se redactó en un castellano trufado de aragonesismos, que irían desapareciendo de manera progresiva en la segunda mitad del siglo XV, época en que se consuma el proceso de castellanización. Germà Colón afirma: «Fernando I, Alfonso V, Juan II y Fernando el Católico, todos sin excepción, serán de lengua castellana o aragonesa (tal vez aragonesacastellana)» (1989: 249-250). Por su parte, la autora anteriormente citada dice publicar «la documentación redactada en castellano (o castellano-aragonés)» durante el gobierno de estos monarcas (1997: 9).

5 Éstas son sus palabras: «Le discours d'ouverture prononcé à cette occasion constitue une véritable histoire du règne faite par le monarque lui-même. Cette longue et magistrale apologie vaut la peine d'étre littéralment traduite». Y más adelante: «Ce discours, à la fois si énergique et si habile, dut faire sur les représentants des divers royaumes une vive impression. Les Cortes générales de Monzon votèrent d’importants subsides» (Calmette 1903: 304 y 313). Soldevila también se refiere al relato histórico del parlamento («el qual discurs conté la història dels esdeveniments del seu regnat»), del que reproduce un fragmento (1962: I, 729), ya dado a conocer por Coroleu y Pella, al igual que hiciera Martínez Ferrando (1942: 192).

SCRIPTA, Revista internacional de literatura i cultura medieval i moderna, núm. 8 / desembre 2016 / pp. 25-77 ISSN: 2340-4841 · doi:10.7203/SCRIPTA.8.9287 
David Guixeras \& Agustín Rubio Vela. El parlamento de Juan II ante las cortes generales de Monzón (1469). Una pequeña crónica autobiográfica en lengua castellanoaragonesa

de la guerra y la ruina financiera del Estado. En tan dramáticas circunstancias, sólo la valentía de los aragoneses, la fidelidad de los valencianos, la lealtad de los mallorquines e incluso la decisión de los catalanes leales, habíanle permitido superar el vendaval revolucionario. Pero en el mismo instante de recoger los frutos de tal esfuerzo, todo había quedado en entredicho por la soberbia de los franceses, dispuestos a subyugar a tan noble y arrogante Corona. ¿Lo consentirían ellos? No dudaba el monarca que pondrían sus espadas a su servicio; pero le faltaba dinero. Las mismas Cortes deberían decidir en qué cuantía». Haciendo suyo el juicio de Calmette, entendía Vicens que el rey habría conseguido lo que se proponía gracias a su larga pieza oratoria: «La impresión producida por ese parlamento se tradujo en importantes donativos» (2003: 336). El mismo autor volvió a referirse posteriormente a la dimensión propagandística del «famoso discurso» ante las cortes generales de la Corona de Aragón, en el cual, «resumiendo la historia de la guerra civil y revolución de Cataluña», Juan II manipuló los hechos de manera ostensible: «hallamos una tergiversación sorprendente de la verdad, basada en opiniones disparatadas de la propaganda coetánea a los sucesos referidos» (Vicens Vives 2006: 116). ${ }^{6}$

Más recientemente, Alan Ryder (2007: 202-203) ha prestado de nuevo atención a la intervención del rey ante las cortes. Reproduce, traducidos al inglés, tres párrafos de cierta extensión, subraya el interés del relato histórico que contiene («a detailed rehearsal of events in Catalonia»), y, al igual que otros autores ya citados, señala que la aprobación por los estamentos de los reinos de las subvenciones solicitadas fue resultado de la elocuencia del monarca, «the fruit of his eloquence».

\section{Estructura y contenido}

Una lectura atenta del largo discurso de Juan II — texto complejo, cuidadosamente elaboradorevela que fue concebido con una estructura tripartita. La primera parte es un breve proemio en el que el monarca, haciendo uso de un lenguaje conciso, directo, desprovisto de citas y excesivos artificios retóricos —el mismo que encontraremos hasta el final de la pieza oratoria—, indica que el motivo de la convocatoria de las cortes era la rebelión de los catalanes, y el objetivo adoptar medidas para seguir combatiéndola. Se presenta como soberano modélico que trata a sus vasallos con «benignidat e amor», por lo que quiere abordar con ellos el grave problema de los «insultos e danyos» que estaba sufriendo en el principado, a fin de acordar conjuntamente («ensemble») lo más conveniente (líneas 1-6). A estas palabras iniciales, pocas pero muy elaboradas, que configuran el preceptivo exordio, sigue, casi sin solución de continuidad, la segunda parte, la más amplia y relevante del parlamento (1. 6-224), en la que el rey expone su particular visión de lo acontecido en Cataluña desde el comienzo del reinado hasta la entrada de las tropas del duque de Lorena desde Francia. Concebido como un aspecto más de la justificación de la convocatoria de cortes y de la voluntad real de informar a los súbditos («e dezirvos cómo...»), este prolijo repaso histórico

6 El autor, en la página señalada y en la 122, transcribió dos breves fragmentos del texto conservado en el Archivo de la Corona de Aragón, GC, Cortes 987, 41-46. 
David Guixeras \& Agustín Rubio Vela. El parlamento de Juan II ante las cortes generales de Monzón (1469). Una pequeña crónica autobiográfica en lengua castellanoaragonesa

— sectario- de lo acontecido, que tanto ha llamado la atención de los estudiosos, constituye el cuerpo mismo de la pieza oratoria. Tras él viene la petitio — tercera y última parte (1. 225-255)—, con la solicitud del monarca de que el selecto auditorio, representación del conjunto de sus súbditos, accediera a sus demandas de dinero, armas y hombres para la guerra.

\subsection{El príncipe de Viana y el primer levantamiento}

Apología de sí mismo e inculpación del enemigo. Aunque ambas ideas cardinales afloran en las tres partes del discurso, se hacen especialmente visibles en la segunda, esa singular exposición de índole histórica, que, al estar redactada en primera persona y encaminada a justificar las acciones propias, recuerda inevitablemente — salvadas las distancias — las crónicas autobiográficas de Jaime I y Pedro el Ceremonioso. El soberano intenta convencer de que todos sus actos de gobierno entre 1458 y 1469 estuvieron impulsados por una voluntad benefactora y un deseo de mejora, en contraposición a los de sus enemigos, que trabajarían siempre inducidos por la maldad. Estamos ante la visión maniquea de una década de crisis en la Corona de Aragón, marcada por la insurrección y guerra civil catalana.

Juan II se remonta al momento de su llegada al trono (27 junio de 1458), «después de muerto el senyor rey don Alfonso, hermano nuestro, digno de recordación gloriosa» (1. 6-7), para deslizar sutilmente un juicio crítico de este reinado, que le servirá asimismo para mostrarse como un monarca justo. Afirma que, tras su entronización, considerando «algunos agravios e injusticias» producidos por «la longua absencia» del Magnánimo de los reinos ibéricos, decidió hacer una convocatoria de las cortes aragoneses y catalanas, y preparar la de las valencianas, con el fin de abordar «la reformación» de aquéllos (1.9-12). Fue entonces, durante la celebración de esas cortes, ${ }^{7}$ encaminadas a rectificar el gobierno y acabar con los agravios e injusticias - la culpa recae sobre el prolongado absentismo de su hermano- - cuando tuvo noticia de que Carlos, su hijo, «tractava con algunos adversarios nuestros en Castilla algunas cosas, contrariando al stado nuestro e al pacífico vivir de vosotros» (1. 14-15). Aunque no utiliza la palabra, acusa de traición al príncipe de Viana, y asegura que fue informado de la grave acción de su hijo por personas de plena confianza. ${ }^{8}$ A continuación abunda en la idea, al presentar la guerra civil que había arruinado el reino de Navarra durante la década anterior como consecuencia de las maniobras de sus enemigos, que habrían instigado a la «inobediencia» a don Carlos, hasta el punto de «que era venido pelear con nos a campal batalla» (1. 18-19). Se trata de una referencia a un episodio de la confrontación navarra, la batalla de Aybar — localidad próxima

\footnotetext{
7 Convocadas el 27 de septiembre de 1460, las cortes de Cataluña se habían de celebrar en Lérida (Vicens Vives 2003: 229-231).

8 El almirante Fadrique Enríquez y su hija, la reina Juana, esposa de Juan II, habrían convencido a éste, con pruebas que con el tiempo se demostrarían falsas, de que el príncipe lo traicionaba y negociaba a sus espaldas con el rey de Castilla, según Vicens Vives (2003: 230-232).
} 
David Guixeras \& Agustín Rubio Vela. El parlamento de Juan II ante las cortes generales de Monzón (1469). Una pequeña crónica autobiográfica en lengua castellanoaragonesa

a Sangüesa—, que tuvo lugar el 23 de octubre de 1451 (Zurita: XV, LXV), ${ }^{9}$ resonante derrota de los beaumonteses, tras la cual el príncipe de Viana sufrió cautiverio durante casi dos años, silenciado por su padre en el discurso, en el cual tampoco menciona la partida del hijo hacia Nápoles, al exilio, en mayo de 1456 (Desdevises du Dezert 1889: 226-246; Vicens Vives 2003: 155-170).

Lo que interesa al orador es demostrar que la detención de don Carlos, ordenada el 2 de diciembre de 1460, punto de partida de la insurrección catalana, estaba plenamente justificada. De ahí el recuerdo de aquella desobediencia del príncipe en Navarra. Ese precedente habría sido tenido en cuenta en el momento de adoptar tan grave decisión como era la orden de apresamiento, cuyo objetivo era evitar que en la Corona de Aragón se reprodujeran los hechos que pocos años antes habían causado la ruina de aquel reino. El temor a retornar «a los passados males», acentuado por la denuncia, llevó al padre, «con el consejo de algunos principales de nuestros regnos», a ordenar la detención del príncipe, a fin de poner remedio a la situación «con la intervención e consejo de los ayuntados en las cortes» (1. 20-24).

Tan buenos propósitos se vieron interrumpidos cuando «algunos de Barcelona», viendo «algun tanto comovidos los pueblos» al llegar la noticia de la prisión del príncipe, alentaron la insurrección (1. 2532). El monarca rememora la formación en la capital del principado, por iniciativa del General, de un «consejo de vintisiete personas», que se arrogó tanta «potesta๖» que la suya quedaba casi anulada (1. 35-38); de ese consejo partió una embajada hasta él, que se encontraba en Fraga, para abordar el asunto. ${ }^{10}$ Según el soberano, los embajadores se dirigieron a él de manera insolente, con «palabras e razones tales que eran más dispuestas provocarnos a indignación que a benignidad» (1. 40-41). ${ }^{11}$ Lo cual era — asegura — lo que en realidad deseaban quienes enviaron la delegación, a la que, por contra, él dio «aquella razón que al caso convenía» (1. 43-44). Más aún, para negociar en mejores condiciones, marchó a la ciudad de Lérida, y los embajadores con él, «e aquí disposimos e dimos orden a las cosas por ellos suplicadas» (1. 45-46). Nuevamente subraya el contraste entre su actitud, tolerante y conciliadora, y la de los oponentes, «que discordia deseaban» (1. 46-47), y cuya respuesta fue aumentar hasta sesenta el número de miembros de la embajada con el fin de acentuar la presión y conseguir sus «pravos e malvados conceptos» (1. 49). Hipócritamente le habrían manifestado su deseo de negociar — «querer contractar humilmente con nos significaron»—, y él accedió: «E de fecho contractamos e fuemos de acuerdo, según e por la forma por ellos mesmos instada e suplicada» (1. 50-52).

9 En 1457, Juan II ya acusó a su hijo de haber levantado «guerra uberta e veniendo con él a batalla campal en propia persona suya», así como en 1461: «fins a venir en camp de batalla» (Miranda Menacho 2011: 136 y 755).

10 El 5 de diciembre, las cortes catalanas, disueltas por el rey, dieron poder a los diputados del General para que, con el consejo de las personas que designaran y con la intervención de la ciudad de Barcelona, adoptaran las medidas oportunas. Tres días después, en la Casa de la Diputació de la capital, se nombraba una embajada de ocho miembros y un consejo de veintisiete personas, el consell representant lo principat de Catalunya, para reclamar la libertad del príncipe y la defensa de los privilegios y libertades del país (Vicens Vives 2003: 232-233).

11 El día 6, o quizá el 7 de febrero, Guerau Alemany de Cervelló, «un exaltado vianista», leía ante Juan II un «explosivo memorial» redactado el 31 del mes anterior por el consell y la diputació del General (Vicens Vives 2003: 236-237).

SCRIPTA, Revista internacional de literatura i cultura medieval i moderna, núm. 8 / desembre 2016 / pp. 25-77 ISSN: 2340-4841 · doi:10.7203/SCRIPTA.8.9287 


\section{David Guixeras \& Agustín Rubio Vela. El parlamento de Juan II ante las cortes generales de Monzón (1469). Una pequeña crónica autobiográfica en lengua castellanoaragonesa}

Estando en esas negociaciones, Juan II asegura haber sido «súbitamente» informado de que algunos «malvados» embajadores, «ensemble con el pueblo de la ciudat», se encaminaban armados a su palacio con el propósito «de poner las manos en nos e matar todos los principales de nuestra casa que allí se fallavan» (1. 53-56). Se refiere, obviamente, al golpe de mano frustrado del día 8 de febrero de 1461, que tuvo como escenario el palacio episcopal de Lérida, donde residía. ${ }^{12}$ Afirma que, avisado poco antes de que los conjurados emprendieran la acción, decidió salir «scondidamente» de Lérida en dirección a Fraga, con lo que quedaron burlados los autores del «feo e detestable insulto», tan inconcebible que «puesto lo viéssemos, no se nos lexava creer» (1. 57-59). Con estas palabras de condena, el rey subrayaba ante las cortes generales el comportamiento criminal y traidor de los artífices de uno de los más graves y resonantes acontecimientos de su reinado, del que se hicieron amplio eco los cronistas de la época. ${ }^{13}$

A continuación, Juan II, con el mismo sesgo maniqueo presente en toda su prédica, establece una contraposición entre su talante negociador y la intransigencia y radicalismo de los rebeldes. Lo hace al referirse al envío a Lérida de Beatriz de Pimentel, su cuñada, viuda del infante don Enrique, ${ }^{14}$ y al del maestre de Montesa y Lope Ximénez de Urrea a Barcelona, «por provar si en aquesto algún

12 El 12 de febrero, desde Alcañiz, relataba los hechos en carta a Juan de Moncayo, virrey de Sicilia, a Vidal Castellà d’Orís de Blanes, gobernador de Mallorca, y a Nicolau Carròs d'Arborea, virrey de Cerdeña, publicada por Miranda Menacho (2011: 779-784): «Et a les VIII ores de la nit fom avisats, per quatre o cinch persones principals dels dits LX, com havien delliberat venir a nostre palau alguns d'ells, ab tota la dita gent, e metre les mans e exequtar alguns de nostre consell, axí com eren lo noble e amat conseller nostre, don Pedro d'Urrea, governador de València, lo justícia de Aragó, lo vicecanceller micer Jaume Pau, mossèn Rebolledo, lo comanador de Monçó, mossèn Pero Vaca e micer Johan de Pallach [sic, por Gallach]».

13 El notario barcelonés Jaume Safont lo relata así: «lo senyor rey, qui era a Leyda [...], gran hora de nit, ab dos altres a peu isqué de Leyda per una falça porta qui és en lo mur devant Preÿcadors, e caminà fins que fonch a Ffraga, on era la senyora reyna, sa muller, e fonch ja hora de mijanit com hi fonch junct, de què la dita senyora reyna fonch fort meravellada com axí $l$ viu venir. E los embaxadors de Cathalunya, qui eren en Leyda, ensemps ab los payers de la dita ciutat, muntaren alt al palau del bisbe, on lo dit senyor posava, e cuydant-lo-y trobar per parlar ab ell, trobaren les taules meses e lo tinel perat e les vitualles aperellades per lo sopar del dit senyor, e ell fonch-se'n anat sens sopar» (Sans i Travé 1992: 128-129). Ésta parece haber sido la fuente de Pere Miquel Carbonell (Alcoberro 1997: II, 217). El dietarista valenciano Melcior Miralles, desde una óptica bien diferente, escribe: «E lo senyor rey, vent tals actes tan superbiossos, a les .XI. ores de la nit, ab si quart, per part de l'Estudi yisqueren de la ciutat, molt congoxant dels actes que avien fets en la dita ciutat. $\mathrm{E}$ los misatgés e paés, sentint que 1 senyor rey hera fora e que 's se n'hera anat, fonch tan gran avalot en la dita ciutat que paria que 1 món degués perir, tenint-se per dit que senyor rey ni altra presona los degués contradir» (Rodrigo Lizondo 2011: 299). El cronista castellano Alonso de Palencia, afecto a Juan II, asegura que hubo una conjura por parte de los rebeldes para apoderarse del rey: «Nec mora quin sub pretextu prestitae ad securitatem Caroli principis fidei confestim aduolarent Ilerdam ut regem in ea urbe residentem comprehenderent» (Tate y Lawrance 1998-1999: II, 226). Según la Crónica anónima de Enrique IV de Castilla: «la conjuraçion se fizo entre los de Barçelona e Catalueña, e luego acordaron de prender al rey, que en la çibdat de Lerida estava, lo qual como el rey syntiese, se fue a Fraga, donde la reyna su muger y el infante don Fernando su fijo estavan...» (Sánchez-Parra 1991: 109). Reproduce estas palabras Diego de Valera, «los barçeloneses [...] acordaron de prender al rey, que en la çiudad de Lérida estaua. Lo qual como el rey sintiese se fue a Fraga» (Carriazo 1941: 64). Véanse otros textos posteriores en Rubio Vela 2013 (a): 130-132.

14 Sus negociaciones con los embajadores de Cataluña, ante quienes se presentó el 12 de febrero, duraron cuatro días, según Desdevises du Dezert, quien, equivocadamente, se refirió a ella como «une infante d'Aragon [..], cousine du roi» (1889: 339-341; y Miranda Menacho 2011: 323-325). 
David Guixeras \& Agustín Rubio Vela. El parlamento de Juan II ante las cortes generales de Monzón (1469). Una pequeña crónica autobiográfica en lengua castellanoaragonesa

remedio fallarse pudiera». ${ }^{15} \mathrm{El}$ orador indica que había tratado de ese modo de llegar a un acuerdo satisfactorio, «assí de la detención del príncipe como a todos los otros inconvenientes» (1. 59-64), con los jefes de la revuelta, a los que aludirá en adelante como «los caborales» (1. 65, 71, 95, 102, 146 [caporales]). Intento que habría acabado en fracaso por culpa de quienes componían el consejo de los veintisiete, quienes, deseando siempre, «no concordia, mas rompimiento», respondieron al ofrecimiento de negociación con el envío de «gente armada a cavallo e a pie contra nos» (1. 64-67). ${ }^{16}$ La llegada de las huestes catalanas, que entraron sin resistencia alguna en Fraga, es presentada por el rey como una provocación de los rebeldes a la que él respondió marchando a Zaragoza «por no dar lugar a sus perversos e infides acometimientos». Evita relacionar con esa acción militar la orden de poner en libertad a don Carlos, que se vio obligado a dar el 25 de febrero, esto es, el mismo día de la entrada de aquel ejército en Fraga ${ }^{17}$ la liberación del hijo habría sido un gesto paternal de clemencia, «reconocidas las cosas contra el príncipe opuestas», no una medida adoptada por necesidad, ante la incapacidad de hacer frente a aquellas tropas (1. 67-69). Pero la realidad era bien distinta. Como escribiera Vicens Vives, «el 25 de febrero de 1461 la monarquía capitula, en desastrosas condiciones, ante el levantamiento de Cataluña» (2003: 238). La tergiversación de los hechos en el discurso de Juan II se hace, una vez más, evidente.

Tras la puesta en libertad del príncipe, la marcha a Barcelona de éste y de la reina fue otro intento frustrado de apaciguar, «con benignidat e complazimientos» (1. 70), los ánimos encendidos de los jefes de la revuelta, que en el fondo, según el monarca, hubieran preferido que don Carlos siguiera en prisión, aunque fingieran lo contrario. Con las armas en sus manos, se habrían dispuesto a alcanzar sus verdaderos propósitos; entraron en nuevas negociaciones con la reina, a espaldas del príncipe, y consiguieron «una cierta capitulación» que para el poder real suponía quedar supeditado en Cataluña al de los insurrectos, pero también para el príncipe, pues la autoridad que le dieron éstos era sólo nominal: «que el príncipe no haviese en ellos sino el nombre solo de senyor» (1. 77-80). El monarca afirma que, a pesar de la perversidad de ese documento - la célebre capitulación o concordia de Vilafranca del Penedès (22 de junio de 1461)—, ${ }^{18}$ decidió firmarlo «veyéndolos dispuestos a

15 La llegada a Barcelona de Lluís Despuig, maestre de Montesa, y de Lope Ximénez de Urrea, virrey de Sicilia, tuvo lugar el 6 de febrero según Pere Miquel Carbonell (Alcoberro 1997: II, 216), y las instrucciones que llevaron consigo, dadas por el monarca, llevaban fecha del 31 de enero (Vicens Vives 2003: 235). El envío de los embajadores fue anterior, pues, a los hechos del 8 de febrero, por lo que no pudo ser, contrariamente a lo que Juan II da a entender, un último intento conciliador («por provar si en aquesto algún remedio fallar se pudiera» [1. 59-60]).

16 Se refiere el soberano a la salida de Barcelona del ejército que, bajo el mando del conde de Módica, se apoderó de Fraga el 25 de febrero (Desdevises du Dezert 1889: 343-344).

17 Pere Miquel Carbonell expresa así tal evidencia: «E axí, partint-se com dit és dit exèrcit [del comte de Mòdica] e tirant son camí fins en la vila ho loch de Fraga, lo senyor rey don Juan, sabent que dit exèrcit era junt en lo dit loch de Fraga, delliurà lo dit príncep son fill, tornant-lo en sa libertat» (Alcoberro 1997: II, p. 213).

18 «Pieza capital en la historia del 'pactismo' catalán y del derecho constitucional moderno», a juicio de Vicens Vives (2003: 238 y 240), suponía la aceptación, por parte de la corona, de «una reorganización profunda de la alta administración del Principado, por la cual todas esas autoridades, además de ser naturales de Cataluña o avecindadas en

SCRIPTA, Revista internacional de literatura i cultura medieval i moderna, núm. 8 / desembre 2016 / pp. 25-77 ISSN: $2340-4841 \cdot$ doi:10.7203/SCRIPTA.8.9287 
David Guixeras \& Agustín Rubio Vela. El parlamento de Juan II ante las cortes generales de Monzón (1469). Una pequeña crónica autobiográfica en lengua castellanoaragonesa

qualesquiere maldades». Alcanzaron de ese modo el objetivo deseado: «poder absolutamente regir», reteniendo consigo al príncipe, pero con «poca e quasi ninguna jurisdicción». Juan II relaciona el fallecimiento prematuro de su hijo (23 de septiembre de 1461) con el sufrimiento que habría provocado en él esa situación: «aquesto molestamente sofriendo, cayendo en mortal dolencia, feneció sus días» (1. 82-85).

\subsection{La segunda insurrección}

Se convirtió así en heredero de la corona el príncipe Fernando, hijo de Juan II y de Juana Enríquez, cuya presencia en Barcelona fue exigida por los dirigentes de la revuelta, de acuerdo con lo estipulado en la capitulación de Vilafranca. Para el monarca, la corta edad del sucesor, un niño de once años, beneficiaba a aquéllos, que podrían someterlo fácilmente a su voluntad: «edat dispuesta para poder ellos mejor a la voluntat suya regir». En compañía de la madre - en condición de tutora-, su llegada a Barcelona (21 de noviembre de 1461), no sólo no suavizó la hostilidad de los «caborales», sino que la incrementó, pues, oponiendo la reina «alguna contradicción» a su «absoluto govierno», comenzaron «preparar e mover nuevos scándalos» (1. 89-92). Habría dado pie a ello la agitación campesina iniciada en Cataluña a principios de 1462 (Vicens Vives 2003: 263-266), cuando se levantaron contra sus señores «algunos pageses de remença en las partes del Ampurdán», lo que aprovecharon «los dichos caborales» para instar a la reina y al príncipe a viajar en dirección a Gerona con la finalidad de «castigar e punir» a los insurrectos, aunque el verdadero propósito era alejarlos de Barcelona para ellos «mejor conduzir sus iniquos e malos conceptos al fin deseado» (l. 94-99).

La reina partió de capital catalana el 11 de marzo, con el príncipe, y, una vez llegó a Gerona, procedió contra los campesinos, dos de los cuales fueron encontrados culpables por lo que los hizo ahorcar. ${ }^{19}$ Un dato que Juan II destaca, sin duda para demostrar que la acusación de complicidad de su esposa con los remensas, esgrimida por los «caborales» en Barcelona, ${ }^{20}$ era falsa, que se trataba sólo de una excusa para organizar el ejército que, bajo el mando del conde de Pallars, «so color de

ella durante más de diez años (a excepción del canciller, quien, por otra parte, debería ostentar una prelatura catalana), pasarían a depender económicamente del país y no del rey». El texto ha sido reeditado modernamente por Alcoberro (1997: II, 225-244).

19 El 28 de marzo fue ahorcado un tal Joan Foxà por orden de la reina, que en el mes siguiente se mostraba dispuesta a castigar los desmanes de los remensas «colgando a un nuevo autor de los mismos» (Coll Julià 1953: II, 66).

20 El 11 de junio de 1462, cuando la reina fue declarada en Barcelona «enemiga del Principat de Cathalunya», una de las razones aducidas, según Safont, fue haber sido instigadora de la insurrección de los remensas: «E més avant ab tota veritat haja insultat e fet levar en lo dit Principat cert e assats gran nombre de pagesos, apellats de remença, sots capitania d'un pagès appellat Ffrancesch de Verntallat, qui anava per tota la terra ab oficials e bandera reyal, sforçantse fer moure gents contra gents en lo dit Principat, robants e destruhints les cases de aquells qui no 1 volien seguir, assitiants viles e castells per pendre aquells» (Sans i Travé 1992: 159). 
David Guixeras \& Agustín Rubio Vela. El parlamento de Juan II ante las cortes generales de Monzón (1469). Una pequeña crónica autobiográfica en lengua castellanoaragonesa

castigar los pagesos» (1. 104-105), se dirigió a Gerona contra doña Juana. Efectivamente, el 29 de mayo partió de Barcelona esa hueste, que empezó a prepararse en la última semana del mes anterior «para reprimir, por la fuerza de las armas, los alborotos de los remensas y para proceder contra los infractores de la Capitulación». La noticia causó el recelo, «perfectamente explicable», de la reina, que adoptó «las disposiciones necesarias para que la llegada de aquella potente expedición militar ante los muros de Gerona no la cogiera desprevenida» (Coll Julià 1953: I, 336-337 y 359-361).

A comienzos del mes de junio, gracias a la complicidad de algunos que desde el interior abrieron las puertas, se produjo la entrada de esas tropas en la ciudad. El discurso real subraya el grave peligro que corrieron entonces madre e hijo, quienes habrían estado a punto de ser apresados por la milicia: «con las armas furiosamente entrando, falleció muy poco de tomar la reyna e príncipe, stando descuydados de sus iniquos intentos» (1. 108). Y hace una prolija descripción, no exenta de toques melodramáticos, del asedio a que fueron sometidos cuando se refugiaron en la «Fuerça Vieja» de Gerona el 6 de junio, día de la entrada en la ciudad del ejército del conde de Pallars. Contra ellos dirigieron «lonbardas et mucha otra artellería» durante los combates, «muy fuertes e continuos», con los que intentaron hacerse con la célebre fortaleza, en el curso de los cuales demostraron «inhumanidat e crueza», puesto que no sólo disparaban «a la posada donde sabían que los senyores suyos stavan», sino que no consintieron proporcionar comida, ni siquiera «una poca de fruita, al tierno ninyo» (1. 110-115). Tampoco fueron atendidas las propuestas que, por mediación del canónigo mossèn Cartellà, Juana Enríquez hizo llegar a los sitiadores: ${ }^{21}$ «La respuesta fue que como fuesen entrados les respondrían». Juan II los acusa a continuación de tener decidido, una vez hubieran conseguido entrar, que «fuessen puestos a la spada, ensemble con todos los otros, nuestra muxer e fijo» (1. 118-120).

Aún así, antes de recurrir a la guerra, el monarca asegura haber intentado la paz por la vía diplomática. Habían llegado a Barcelona embajadores del rey Ferrante de Nápoles, su sobrino, y del reino de Valencia, con el objetivo de pedir a los dirigentes de la insurrección que ordenaran levantar el asedio de la força vella gerundense y permitir la salida de la reina y del príncipe, ofreciendo a cambio satisfacer sus demandas, «si algunos agravios o sinrazones pretendiesen, o gracia demandasen» (1. 127-128); ${ }^{22}$ pero desdeñaron los ofrecimientos de los embajadores, demostrando con claridad que

21 En el capítulo dedicado al sitio de la força vella por Coll Julià (1953: II, 7-40), donde hay un apartado referente a «las penalidades sufridas», se alude a la misión de este clérigo, que salió para entrevistarse con el conde de Pallars en dos ocasiones, los días 27 de junio y 2 de julio.

22 Jaume March y Gaspar Talamanca, mayordomo y secretario respectivamente, embajadores de Ferrante, llegaron a Barcelona el 21 de junio (Vicens Vives 2006: 127). El 4 de julio consideraban los diputados la «resposta e expedició» que se habría de dar a los «embaxadors del rey de Nàpols que han referit venir del S. Rey ab certes coses per ells explicades o reportades» (Bofarull y de Sartorio 1858-1864: XI, 243-244). Hacia mediados de junio, se comenzó a tratar en Valencia el envío de la embajada conciliadora al principado que llegó el 19 de julio a Barcelona y retornó en septiembre sin haber conseguido fruto alguno (Vicens Vives 2006: 127-128; Sobrequés i Vidal y Sobrequés i Callicó 1973: II, 134-139). Esta fue la segunda embajada valenciana, ya que en 1461, en vida de Carlos de Viana, se envió otra, recientemente estudiada (Rubio Vela 2016: 39-73). 
David Guixeras \& Agustín Rubio Vela. El parlamento de Juan II ante las cortes generales de Monzón (1469). Una pequeña crónica autobiográfica en lengua castellanoaragonesa

sólo deseaban «la senyoría» (1. 132). Así pues, no le quedó más remedio que tomar las armas contra los rebeldes de Cataluña. Y, dado que Enrique IV de Castilla estaba dispuesto a ayudarlos, acordó con Luis XI de Francia un apoyo militar «fasta haver reduzido a obediencia nuestros vasallos» (1. 137), en virtud del cual éste enviaría un ejército de seiscientas lanzas a cambio del pago de doscientos mil escudos, quedando las rentas del condado de Rosellón y la Cerdaña en su poder hasta que no cobrase la cantidad citada. ${ }^{23}$ Pretendía con estas palabras justificar una actuación que los catalanes presentaron como un crimen de lesa majestad al tratarse de la entrega de una parte del territorio patrio a un rey extranjero.

Al llegar a este punto, el monarca, sin duda conocedor de los argumentos que la propaganda de sus enemigos esgrimía contra él, interrumpe el orden cronológico del relato para legitimar su actuación y, al mismo tiempo, arremeter contra Luis XI. En 1469, cuando pronunciaba el discurso ante las cortes generales de la Corona de Aragón, el antiguo aliado había dejado de serlo, pasando a convertirse en su gran enemigo. Juan II denuncia esa traición: el rey francés, que rompió el juramento hecho y se había adueñado, «injustamente e sin nuestro consentimiento» (1. 140-141), del Rosellón y la Cerdaña. No fue una entrega de territorios catalanes a Francia, pues, sino una apropiación ilegítima de éstos por parte del monarca francés.

Siete años atrás, la situación era muy distinta. Las relaciones entre ambos soberanos eran cordiales y firmaron una alianza, gracias a la cual Juan II pudo contar con la oportuna ayuda militar desde más allá del Pirineo en un momento crítico. Efectivamente, las tropas que llegaron bajo el mando de Gaston de Foix hicieron posible que la reina Juana y el príncipe Fernando pudieran verse libres de las «crueles manos» (1. 144) de los sitiadores de la força vella: el 23 de julio de 1462, el conde de Foix entraba en Gerona tras haber obligado al ejército de la Generalitat a alzar el cerco (Coll Julià 1953: II, 24-25). El orador presenta la liberación de su esposa e hijo como consecuencia del socorro de «la gente francessa», por él gestionado, pero insinúa, de manera engañosa —utiliza términos intencionadamente confusos-, que la acción liberadora fue también mérito suyo, ya que él acudió a Balaguer «a fin de socorrer nuestra mujer e fijo e tantos buenos con ellos encerrados» (1. 142-143). Se refería a su entrada en el principado, a comienzos de junio, al frente de un ejército que se estableció en Balaguer, contra el cual Barcelona envió una hueste que resultó derrotada en la célebre batalla de Rubinat. El encuentro se produjo el mismo día que, bien lejos de allí, en Gerona, era liberada Juana Enríquez por Gaston de Foix (Vicens Vives 2003: 280-281). ${ }^{24}$

23 Una vez más, el rey falsea la cronología de los hechos para acomodarlos a su conveniencia. El tratado de Salvatierra fue firmado el 3 de mayo de 1462, tras entrevistarse personalmente Juan II y Luis XI. Era una realidad, pues, antes de la salida de las tropas del conde de Pallars hacia Gerona, y la propia reina dio noticia del acuerdo a mediados de ese mismo mes a las autoridades de Barcelona (Vicens Vives 2003: 276-278). En modo alguno fue ese último recurso al que el orador asegura haber acudido para salvar a su esposa e hijo tras fracasar todos los intentos de conciliación.

24 El día 16 de junio partió desde Barcelona la hueste que «tirà la via de Balaguer, on lo rey en Joan era entrat dies havia ab certa gent d'armes», según el dietarista barcelonés Jaume Safont; el 23 se produjo el encuentro entre ambos ejércitos junto al castillo de Rubinat («la batalla qui fonch lo dit die, devant lo castell de Rabinat»), donde, tras un duro combate,

SCRIPTA, Revista internacional de literatura i cultura medieval i moderna, núm. 8 / desembre 2016 / pp. 25-77 ISSN: $2340-4841 \cdot$ doi:10.7203/SCRIPTA.8.9287 
David Guixeras \& Agustín Rubio Vela. El parlamento de Juan II ante las cortes generales de Monzón (1469). Una pequeña crónica autobiográfica en lengua castellanoaragonesa

\subsection{La guerra civil}

Mientras todo esto sucedía, los «caporales del consejo» consiguieron extender la rebelión a casi toda Cataluña, según Juan II, con «infinitas cautelas, stucias e falsedades», producto de una maldad que habría quedado al descubierto (1. 145-147). El tono acusador del soberano se acrecienta conforme avanza el relato de los hechos en el discurso. Denuncia cómo los insurrectos, sus propios vasallos, usurpando la legítima soberanía real y adoptando «forma de común regimiento», lo declararon «capital enemigo», acción que califica de «cosa enorma, detestable e inaudita» (1. 149-152); ${ }^{25}$ cómo tomaron las armas contra él, aunque «mediante la divina justicia siempre vencidos» (1. 153-154), y cómo ofrecieron sucesivamente la soberanía que le fue usurpada a enemigos suyos. En primer lugar, a Enrique IV de Castilla, cuya renuncia a la corona, tras haberla aceptado inicialmente y ejercido durante más de un año, presenta como un acto de menosprecio hacia los rebeldes, que habrían sido «desechados» (1. 156) por el monarca castellano. ${ }^{26}$ Tras lo cual hubo — asegura el orador- un amago de ofrecimiento del trono al rey de Francia, que se habría visto frustrado por la previsible oposición popular, dada la animadversión de «los menudos pueblos, aborresciendo la senyoría francessa» (1. 157-158). ${ }^{27}$ Finalmente titularon rey de Aragón a don Pedro de Portugal. Juan II se limita a mencionar al condestable luso que fue soberano nominal de los catalanes durante casi tres años, desde el 27 de octubre de 1463, fecha de su proclamación en Barcelona, hasta el 29 de junio de 1466, el día de su muerte prematura (Martínez Ferrando 1942: 91 y 166). Y prosigue indicando cómo, tras producirse el óbito, los rebeldes, «endurecidos en su pertinacia» y menospreciando los intentos pacificadores del papa, que les habría enviado un nuncio ${ }^{28}$ para exortarlos a buscar el

el monarca derrotó a las tropas catalanas (Sans i Travé 1992: 163 y 165-166). Valencia celebró esta victoria del rey sobre «los cathalans rebel les, prop lo castell de Rabinats» (Rubio Vela 1998: 282-283).

25 El 9 de junio, tras su entrada en Cataluña al frente de un ejército, el rey era declarado «persona privada e enemich de la cosa pública», y cuatro días después lo era la reina. El archivero y cronista Pere Miquel Carbonell califica de «rigurosa y damnada crida» el pregón que dio a conocer la noticia en Barcelona, «que may en aquest principat de Catalunya crech sia estada feta tal ne semblant», y confiesa que, al oirla, «me n’enugí molt e plorí» (Alcoberro 1997: II, 211-212).

26 El 11 de agosto de 1462, Juan II fue depuesto por una comisión designada por el Consell del Principat, que proclamó rey de Aragón a Enrique de Castilla; éste se vería obligado a renunciar en octubre del año siguiente, obligado por la sentencia arbitral de Bayona (Sobrequés i Vidal y Sobrequés i Callicó 1973: II, 373-376 y 454-464). La propaganda realista utilizó la animadversión histórica hacia Castilla de los catalanes para atacar tanto a los insurrectos como a Enrique (Nicolau d'Olwer 1934: 323-324, 326 y 333).

27 La versión de Juan II se aleja de la verdad histórica. Fue Luis XI quien mostró interés, aunque de manera soterrada, en la incorporación de Cataluña a sus estados, y los dirigentes del principado quienes, «forjados en el ánimo tradicional de hostilidad hacia Francia», no entraron en el ofrecimiento (Vicens Vives 2003: 288).

28 Ese nuncio papal podría ser Antonio Jacopo Venier, que se encontraba en los reinos hispánicos desde comienzos de 1458 «cum plena potestate legatio a latere», y que desde ese año hasta 1464 aparece «en todos los problemas eclesiásticos de la época» (Vicens Vives 2006: 231; Suárez Fernández 2002: 376). Es sabido que Roma no vio con buenos ojos, desde un principio, la revuelta de la Generalitat. Pío II (1458-1464) vio desfavorablemente la intervención de Pedro de Portugal, y la elección de su sucesor, Pablo II (1464-1471) no supuso un cambio (Martínez Ferrando 1942: 115-120).

SCRIPTA, Revista internacional de literatura i cultura medieval i moderna, núm. 8 / desembre 2016 / pp. 25-77 ISSN: $2340-4841 \cdot$ doi:10.7203/SCRIPTA.8.9287 


\section{David Guixeras \& Agustín Rubio Vela. El parlamento de Juan II ante las cortes generales de Monzón (1469). Una pequeña crónica autobiográfica en lengua castellanoaragonesa}

camino de la concordia con su rey y señor, acordaron ofrecer el trono a Renato de Anjou, «el duque Reyner» (1. 163-164). La decisión, adoptada el 30 julio de 1466 (Muxella Prat 2000-2001: 219), había convertido a éste en soberano nominal de la Corona de Aragón, y como tal actuaba entonces, cuando Juan II disertaba ante las cortes generales.

Tras este breve repaso de lo que había sucedido desde 1462 hasta entonces, el rey pasó a referirse al conflicto bélico propiamente dicho, poniendo de manifiesto, en primer lugar, que él se había visto forzado a tomar las armas ante el fracaso de todos los intentos de pacificación y concordia: «ha convenido a nos, como forçado, guerrear con nuestros mesmos vassallos e destruir e gastar nuestros proprios bienes» (1. 172-173). La paciencia real ante los «malvados insultos» (1. 168) de los rebeldes se había demostrado remedio ineficaz, por lo que hubo de recurrir a la lucha armada «a fin de alcançar paç»; lo cual había supuesto para él extraordinarios sacrificios y pérdidas, pues en los años últimos hubo de renunciar a «toda natura de plazeres», tuvo que exponerse a «trebaxos, periglos e infortunios» y padecer una verdadera sangría económica (1. 173-177). Ahora bien, para hacer frente a los insurrectos, que habían actuado «sin perdonar a nuestra edat nin guardar a la real preheminencia», el monarca dice no haber estado solo. Había contado con el apoyo de todos sus súbditos: de los aragoneses, «exemplo de lealdat entre todas las naciones» (1. 184-185); de los valencianos, que cada vez que se había producido una «offensión» en el interior del reino la han «animosamente opugnada e expellida», ${ }^{29}$ y cuyos servicios han sido tan valiosos «que no solamente nos, mas los descendientes nuestros quedan en obligación de vosotros» (1. 187-190); de los mallorquines, que proporcionaron ayuda naval: «havemos recebido por la mar tales e tantas valenças que han mostrado no passarles en voluntat ningunos de los otros vasallos» (1. 190-192); ${ }^{30}$ y de los catalanes «leales e fieles», que habían derramado su sangre, abandonado sus hogares y perdido su patrimonio por defender al rey, víctima de «la infidelidat e maldat de los rebelles» (1. 194-195). El monarca, siguiendo una vieja tradición, hace una laudatio de los súbditos similar a la que acostumbraron hacer en sus propuestas ante las cortes generales quienes le precedieron en el trono. ${ }^{31}$

29 El monarca alude a los dos alzamientos contra él que en 1462 tuvieron lugar en el reino de Valencia, con el apoyo del principado rebelde y de tropas llegadas de Castilla. Fueron sus protagonistas Joan de Cardona, que había sido hombre muy próximo al príncipe de Viana, y Jaume d'Aragó. Ambos nobles valencianos, que se hicieron titular duques, respectivamente, de Gandia y de Segorbe, encabezaron simultáneamente los dos episodios insurreccionales, que tuvieron como epicentros Ondara (condado de Dénia) y Villahermosa (baronía de Arenós). Combatidos desde el interior por tropas valencianas, fracasaron en su intento de extender a todo el reino la rebelión catalana. Sobre el primero, vid. el apartado titulado «Joan de Cardona, el condado y una guerra ignorada, 1462 y 1463» (Rubio Vela 2013 [b]: 574-584); sobre el segundo vid. Llorca s. d.: 15-59.

30 La ciudad e isla de Mallorca se mantuvo adicta a Juan II, y desde el principio el gobernador realizó acciones hostiles contra embarcaciones del principado (Sobrequés i Vidal y Sobrequés i Callicó 1973: I, 348). En 1466, las naves mallorquinas reforzaban la flota realista en la toma del castillo de Amposta (Martínez Ferrando 1942: 159).

31 Pere Miquel Carbonell transcribió algunas, publicadas como apéndice en Cròniques d’Espanya: «en les quals [proposicions fetes per los reys de Aragó] són lohats y comendats tots los vassalls de lurs loables e grans senyories, y especialment los cathalans de haver fet y mostrat per obra de fidelitat, amor e liberalitat en metre béns e persones per subvenir y ajudar a lurs reys, prínceps e senyors posats en congoixes y necessitats» (Alcoberro 1997: II, 249-259).

SCRIPTA, Revista internacional de literatura i cultura medieval i moderna, núm. 8 / desembre 2016 / pp. 25-77 ISSN: $2340-4841 \cdot$ doi:10.7203/SCRIPTA.8.9287 
David Guixeras \& Agustín Rubio Vela. El parlamento de Juan II ante las cortes generales de Monzón (1469). Una pequeña crónica autobiográfica en lengua castellanoaragonesa

La retórica del patriotismo, también propia de los discursos ceremoniales ante las cortes (Albert y Gassiot 1928: 10-11), estuvo, pues, presente. El soberano la utiliza con habilidad, siempre para halagar a sus súbditos, a los que elogia por su extraordinaria disposición en el manejo de las armas: «por cierto entre todas las naciones del mundo soys vosotros en el exercicio de las armas singularmente dispuestos» (1. 231-232). También recurre al sentimiento patriótico cuando acusa a los rebeldes de buscar el sometimiento de los súbditos de la Corona de Aragón, pueblo de conquistadores, a la insoportable soberanía de los franceses, los enemigos históricos: «trabayan continuamente que vosotros, de tantas gentes conquistadores, hayáys de ser conquistados a mano suya de franceses, antigos enemigos vuestros, la dura e superba senyoría de los quales pudo jamás ninguna nación soportar» (1. 216-219). ${ }^{32}$ E insiste: «vosotros, de quien recuerdan los tantos vencimientos, las tantas ofensas con tantos derramamientos de sangre fechos en ellos por vuestros antecessores!» (1. 220222). El objetivo era presentar la entrada de tropas en Cataluña bajo el mando del duque de Lorena como una invasión del ancestral enemigo, deseoso de venganza: «La vengança de las quales cosas prosiguiendo, son ya con las armas en las manos, no solamente dentro la patria, mas asaz vezinos de aquí» (1. 222-224).

Soberano legítimo y señor natural de catalanes, aragoneses, valencianos y mallorquines, manifiesta ante la asamblea parlamentaria la confianza en todos ellos, servidores fieles suyos, como lo habían sido de sus antepasados las generaciones precedentes: «vosotros e vuestros antecessores con acostunbrada fidelidat e virtut havéys acostunbrado fazer vers los otros reyes de gloriosa memoria e nos». Lo cual, además de un servicio a Dios y un beneficio para «la república de todos nuestros regnos e tierras», supondría para ellos como colectividad, como súbditos de la monarquía catalanoaragonesa, el «renombre e fama inmortal de todos vosotros» (1. 251-255). La recompensa espiritual más valiosa para un pueblo en pie de guerra.

Contrasta el prolijo relato que hace Juan II de los acontecimientos que precedieron a la contienda con la parquedad extrema con la que se refiere a ésta en la parte final del discurso. Nada tiene de extraño que no mencione ninguna derrota. No alude a la acción militar de Viladamat - 21 de noviembre de 1467-, causante de la situación de peligro que había motivado la convocatoria de las cortes generales. ${ }^{33}$ Pero llama la atención el hecho de que tampoco hiciera alarde de ninguna victoria concreta en campo de batalla: ni siquiera cita los resonantes éxitos de Rubinat (1462) y Calaf (1465), tan celebrados y comentados por los propagandistas de su facción (Rubio Vela 2012:

$32 \mathrm{Al}$ esgrimir este «argumento de peso en favor de su causa», el rey «tenía la seguridad de que muchos comulgarían con su modo de pensan» (Vicens Vives 2006: 179).

33 «En Vilademat, cerca de Gerona, las fuerzas del duque de Lorena y de la Generalidad sorprendieron a un convoy de víveres que los realistas pretendían hacer llegar a Gerona. En la acción (21 de noviembre de 1467) cayeron prisioneros los más significados adalides de la causa de Juan II, y el propio príncipe don Fernando se libró del cautiverio gracias al valor con que defendió su persona Rodrigo de Rebolledo. De todos es conocido el resultado de la derrota. Los realistas fueron barridos del Ampurdán y quedó preparado el terreno para que Juan de Lorena se apoderara de Castellón de Ampurias el 15 de abril de 1468» (Vicens Vives 1952: 262; y 2006: 189-191). 
David Guixeras \& Agustín Rubio Vela. El parlamento de Juan II ante las cortes generales de Monzón (1469). Una pequeña crónica autobiográfica en lengua castellanoaragonesa

II, 118-119, 125, 129, 131, 133, 286 y 290). Prefirió presentar la confrontación como un proceso en el que sus enemigos, «tomadas las armas abiertamente contra nos, fueron mediante la divina justicia siempre vencidos» (1.153-154), y que estaba ya tocando a su fin. A lo largo de los años de la contienda, la triunfal actuación conjunta del monarca y sus leales vasallos había permitido recuperar una parte del territorio del principado: «Con vosotros ensemble havemos ganado Lérida, tomado Cervera, cobrado Tortosa e, finalmente, gran part de Cathalunya» (1. 203-205). La conquista de estas tres importantes ciudades, que capitularon ante las tropas realistas, respectivamente, el 6 de julio de 1464, el 14 de agosto de 1465 y el 15 de julio de 1466 (Vicens Vives 2003: 296, 302 y 305), permite a Juan II presentar su solicitud de ayuda como un último esfuerzo militar para acabar debidamente lo comenzado tiempo atrás con tanto éxito.

\section{Legitimidad y soberania: La batalla propagandística}

En la Baja Edad Media, en sus discursos ceremoniales ante las cortes, siempre rodeados de teatral solemnidad, los reyes solían referirse a los fundamentos mismos de su autoridad, esgrimiendo para ello nociones y argumentos de carácter religioso, jurídico y político. Esas piezas oratorias, abundantes en citas extraídas tanto de los textos sagrados como de obras de teólogos, santos, jurisconsultos, e incluso de autores clásicos, no constituían sólo un alarde de cultura o de saberes retóricos; eran, sobre todo, textos propagandísticos destinados a proclamar la legitimidad de la monarquía y a reivindicar sus actos de gobierno (Albert y Gassiot 1928: 12 y 14; Nieto Soria 1993: 69-71; Cátedra 1985-1986: 28-34). La comprensión del parlamento dirigido por Juan II en 1469 a las cortes generales exige situarlo y analizarlo en ese marco.

Con el ritual simbólico característico — «seÿt sobre lo cadafal en una cadira real molt ornadament»—, el soberano en persona pronunció su sermón laico «ab alta e intel ligible veu», con la intención evidente de conseguir el apoyo necesario para hacer frente a una guerra. Y, para justificar esa solicitud de ayuda, expone desde su particular visión, según hemos visto, la génesis del conflicto a fin de demostrar que él siempre había actuado como rey justo frente a unos súbditos injustamente sublevados contra su señor natural. Juan II se instala, pues, en un combate ideológico, paralelo al de las armas, y adopta una estrategia de ataque radical, virulento, contra sus émulos. Desde esta perspectiva se entiende la singularidad de un discurso - probablemente elaborado con la intervención de algún secretario- que prescinde de los adornos y citas que pueblan los textos de esta naturaleza, para adoptar una fórmula, la del relato autobiográfico, que permite al orador exponer sus vivencias con fuerza, verismo e incluso emotividad. ${ }^{34}$ No se concibió como el discurso solemne de un rey que teoriza sobre el buen gobierno, sino como la exposición de un rey que

34 Con la llegada de la dinastía Trastámara, las intervenciones reales en las cortes, carentes del valor formal y de la erudición religiosa y profana de las de sus antecesores, no habrían sido elaboradas por los monarcas, sino por los secretarios, y su finalidad esencial siempre habría sido obtener subsidios, hasta el punto de que «només per fórmula el rei demana consell i exposa els principals afers», según Albert y Gassiot (1928: 12). 
David Guixeras \& Agustín Rubio Vela. El parlamento de Juan II ante las cortes generales de Monzón (1469). Una pequeña crónica autobiográfica en lengua castellanoaragonesa

justifica su comportamiento y presenta sus acciones como las propias de un monarca virtuoso. Frente a las de sus súbditos rebeldes, encarnación del mal.

Efectivamente, centro mismo de la diana a la que dirige sus dardos, los dirigentes de la insurrección del principado serían un grupo reducido — «algunos de Barcelona» (1. 25)—, de hombres ricos, deseosos de un poder que sólo al soberano correspondía. Ensoberbecidos por la riqueza conseguida en tiempos anteriores, habían ido recabando de la corona un cúmulo de privilegios que, de facto, hacían que la jurisdicción suprema quedara en sus manos, de manera que podían hacer alarde de que no había poder superior al suyo: «se desdenyavan ya de tener superior ninguno; e, puesto que lo tuviesen, quisieran que fuese solamente de nombre» (1. 29-31). El poder de la realeza, ya de por sí muy disminuido - insinúa como causa la larga ausencia de Alfonso el Magnánimo, de la que derivaron «algunos agravios e injusticias» (1. 9)—, habría sido usurpado de manera bien clara cuando los dirigentes de la rebelión constituyeron en Barcelona, tras la prisión del príncipe de Viana, el consejo de los veintisiete. Juan II es rotundo al respecto: «la potestat del qual amplificaron tanto que en respecto de aquella restava la nuestra quasi ninguna» (1. 37-38).

La concordia de Vilafranca consagraría institucionalmente, más adelante, la privación de los derechos legítimos del rey. Según ese documento, fruto, según el rey, de la perversidad de sus oponentes, pero que tuvo que firmar para evitar males mayores, «no quedava más senyoría en Catalunya a nos que quanto a ellos pluguiese, e que el príncipe no haviese en ellos sino el nombre solo de senyor» (1. 78-80). Alcanzaron así su principal objetivo, que no era otro sino el de actuar como poder único y exclusivo: «poder absolutamente regir» (1. 83). No sólo él, el propio Juan II, se habría visto privado de sus derechos, sino también su hijo, el príncipe Carlos, al que dejaron casi sin jurisdicción. Y recalca que la finalidad de los insurrectos era apropiarse de la soberanía. Lo hacía para poner de manifiesto la gravedad de esa apropiación, pues en la época se consideraba que la soberanía era un derecho inherente a la condición real y exclusivo de ella, un monopolio de la corona, fundamento de su supremacía absoluta sobre todas las otras jurisdicciones (Carrasco Manchado 2000: I, 144). De ahí que todos los intentos de concordia fracasaran, pues el objetivo de los rebeldes era atribuirse lo que nunca podría ser suyo: «significaron asaz claramente ninguna otra cosa plazerles sino la senyoría» (1. 132). Y de ahí también la necesidad de emprender una guerra contra ellos, «vassallos entendiendo e pugnando continuamente quitar el stado e vida a su natural senyor». Una guerra justa, que, además de perseguir la paz, tenía como finalidad «reduzir los que andan assí errados a vera obediencia de nos, su rey e senyor natural» (1. 227-228).

En el origen de todo ello estaría un pecado capital: la soberbia. Según Juan II, era tan desmesurada la de los dirigentes catalanes — «la superbia suya [...] tanto extrema»— que no sólo les había llevado a la «iniqua rebellión contra nos», sino a disponer a su antojo de la corona: «haver, quitar e poner rey al arbitrio suyo a reynos tanto insignes, e dar senyor a personas tanto preheminentes» (1. 212-215). El peligro de caer en el mismo pecado que había llevado a los ángeles a alzarse en el cielo contra 
David Guixeras \& Agustín Rubio Vela. El parlamento de Juan II ante las cortes generales de Monzón (1469). Una pequeña crónica autobiográfica en lengua castellanoaragonesa

Dios, insinuado por los patricios valencianos en una epístola que dirigieron a los diputats y consell de Cataluña a mediados de junio de $1462,{ }^{35}$ pronto se convertiría en acusación directa y descarnada, en tópico de gran éxito entre los propagandistas de la causa del monarca. Recordemos al respecto algunas frases de Melcior Miralles: «E lo senyor rey, sentint e sabent los fets de Cataluna, e que ab supèrbia e ergulvolien venir ab ell...»; «los catalans muntaven e aumentaven en molta e gran supèrbia, la qual no plau a nostre senyor Déu, car Lucifer ne fonch lançat de paradis»; «tot lo que per ells hera fet ni dit ni ordenat no podien errar, confiant tant de lur sabiesses e gran consel, no recordant-se 'Qui se exaltat, humiliabitur', e que a Déu no plau supèrbia contra son senyor»; «Per què us dich que libertat demanàveu ab supèrbia» (Rodrigo Lizondo 2011: 294, 301, 342 y 384; otros ejemplos en Rubio Vela 2012: 131 y 139).

También en el discurso de 1469 hay una clara utilización del tópico de la soberbia, vinculado a la circunstancia que supuestamente lo habría causado. Aparece en estas palabras acusadoras: «elevados e ensuperbecidos por las muchas e excessas riquezas» (1. 26). Y es evidente que la extraordinaria acogida que se le dio en la propaganda juanista. Así, el dietarista valenciano citado anteriormente escribe: «E Barcelona, vent-se ab tanta prosperitat de multitut de consel de tants e tan grans senyors, abundantment requissima en multitut de pecunies, no ab humilitat, ni portant honor ni reverència a son senyor rey, ans ab molta supèrbia, fan moltes provesions ultra mesura»; "per los molts actes de luable memòria que ls catalans an fets, com per lo molt gran consel, com per lo tant principat, com per la grandíssima abundància de moltes pecúnies». Y más adelante: «los senyors del dit principat foren exalçats en sos coratges que merexien ésser senyors del món [...], tot lo que per ells hera fet ni dit ni ordenat no podien errar, confiant tant de lur sabiesses e gran consel, no recordant-se 'Qui se exaltat, humiliabitur', e que a Déu no plau supèrbia contra son senyor» (Rodrigo Lizondo 2011: 295 y 342).

Fue, sin embargo, entre los cronistas castellanos donde tuvo más eco. Alonso de Palencia lo recogió en su Gesta hispaniensia: «Narrare satis nequeo quam foelix Barchinonensium fortuna erat dum rex Alfonsus apud Neapolim haud infoelicius regnauit. Sed quum exuberantissima opulentia solita est superbiam ingenerare, quae caput omnium malorum est intumuere animi ciuium, et in dies insolentius elati coegere astutissimum regem ad disseminationem simultatum, ut concordia ciuium locupletissimorum non pareret eximiae libertatis audaciam, ad quam semper illa ciuitas inter nobiliores Europe urbes haud inferior aspirabat» (Tate y Lawrance 1998-1999: II, 225-226). El autor de la Crónica anónima de Enrique IV de Castilla lo traduce así: «¿Quien podria dezir la grand feliçidad que los barçeloneses tovieron en el tienpo quel ylustrisimo rey don Alfonso en el reyno de Napol estovo? E con todo esso atentaron de aver lybertad, e regirse por comunidat, sin obedesçer yugo real; a lo qual pensar les dio osadia la gran riqueça, de donde tan gran sobervia conçibieron, la qual

35 «Emperò, deveu tantes prudències, reverències e virtuts considerar, e molt atendre que lo enemich de Déu, Satanàs, príncep de divissió, en lo cel, tantost que fonch per Déu en la pus excelent natura creat, conturbà totes les angèliques jera[r]chies e aqueles constituí en discòrdia» (Rubio Vela 1998: 150-154).

SCRIPTA, Revista internacional de literatura i cultura medieval i moderna, núm. 8 / desembre 2016 / pp. 25-77 ISSN: 2340-4841 · doi:10.7203/SCRIPTA.8.9287 
David Guixeras \& Agustín Rubio Vela. El parlamento de Juan II ante las cortes generales de Monzón (1469). Una pequeña crónica autobiográfica en lengua castellanoaragonesa

suele muchas vezes derribar a aquellos que la tienen [...] e con gran pertinaçia perdieron el seso, pensando entre todos los onbres ser ellos los mas sabios, publicando osadamente que sy Dios oviese menester consejo, no en otra parte que en Barçelona lo hallaria» (Sánchez-Parra 1991: 108). ${ }^{36}$

Visto así, el discurso parlamentario de Juan II se nos vuelve a mostrar en su dimensión propagandística más pura, como verdadera arma de combate ideológico en tiempos de guerra. El monarca, con o sin la ayuda de alguno de sus secretarios, lo concibió como una exposición de hechos del pasado reciente relatados en primera persona, no con la intención de deslumbrar a sus oyentes con palabras bellas y citas cultas, sino para poner de relieve la maldad de sus adversarios y que éstos también eran enemigos de sus súbditos. Con la frialdad propia de su temperamento, aquel soberano «cauteloso en el discurso, calculador en la acción, acerado en la pugna política, inmutable en sus decisiones» (Vicens Vives 2006: 16), elaboró una pieza oratoria destinada a persuadir a los representantes de los reinos de que debían aprobar los fondos, las armas y los hombres que solicitaba. Para ello tenía que conseguir que el auditorio se sintiera solidario con él, que se identificara plenamente con su causa. Y esto le llevó a hacer la sesgada y parcial exposición de los acontecimientos históricos que acabamos de estudiar, con la pretensión de demostrar que él, desde el principio, siempre había luchado por el bien y la justicia.

\section{Aspectos filológicos}

\subsection{Los recursos retóricos}

En la sesión inicial de las asambleas parlamentarias de la Edad Media, los monarcas pronunciaban ante los estamentos de sus reinos un solemne discurso en el que, tras referirse al estado político del territorio, con consideraciones acerca del buen gobierno, exponían su «proposición», objeto específico de la reunión, que por lo habitual era una petición de subsidios. En la Corona de Aragón, estas piezas oratorias solían ser una auténtica exhibición de valores formales, verdaderos semones en los que se hacía alarde de erudición sagrada y profana, en los que abundaban las citas de evangélicas y de salmos, de padres de la Iglesia y de autores clásicos. El célebre parlamento que pronunció Martín el Humano en Perpiñán el año 1406, considerado «l'obra millor que hagi produït l'oratòria a Catalunya» (Albert y Gassiot 1928: 11), ${ }^{37}$ marcó un hito, pero también un final. Con la llegada de

36 Le sigue al pie de la letra Diego de Valera, que escribió en el Memorial de diversas hazañas: «les dió osadía la gran riqueza, de donde tan gran soberuia consiguieron [...] y con gran pertinacia perdieron el seso, pensando entre todos los hombres ser ellos los más sabios, publicando osadamente que si Dios oviese mester consejo, no en otra parte que en Barçelona lo fallaría» (Carriazo 1941: 63). Vid. Rubio Vela 2012: II, 141-142.

37 A propósito de la pieza, Rubió i Balaguer escribe: «La suggestió clàssica és completa. La tècnica del discurs, en canvi, és medieval i no gaire allunyada de les normes d'una Ars praedicandi. La divisió del tema principal és feta en similicadència, a l'igual que l'anàlisi de la manera com els catalans han guanyat fama». Y añade pocas líneas más 
David Guixeras \& Agustín Rubio Vela. El parlamento de Juan II ante las cortes generales de Monzón (1469). Una pequeña crónica autobiográfica en lengua castellanoaragonesa

los Trastámara se produjo un cambio de rumbo. Rubió i Balaguer señaló que la entronización de la nueva dinastía significó el alejamiento definitivo del modelo del sermón religioso en la oratoria parlamentaria; a partir del reinado de Martín I, los discursos reales «ja no afecten l'estil de sermó, ni comencen amb un tema bíblic, i són més directes i concrets»; un cambio que supuso ciertamente un empobrecimiento, aunque también evitó los excesos retóricos —'effeminata consonantiae cantilena'- que denunciaba el humanista Coluccio Salutati (Rubió i Balaguer 1984: 270-271). En similar dirección apuntan Albert y Gassiot (1928: 11-12), para quienes los parlamentos reales, a partir de Martín I, estarían impregnados de pragmatismo, dominados por la demanda material: «només per fórmula el rei demana consell i exposa els principals afers».

El discurso de Juan II ante las cortes generales de 1469 responde a esta intención pragmática y alejada de adornos eruditos. Ahora bien, ello no significa ni descuido en la organización y estructura del texto, según hemos visto en páginas anteriores, ni desinterés por la forma, como vamos a ver a continuación.

Sin ser un ejemplo brillante, el discurso presenta algunas de las características del estilo cancilleresco, la más evidente de las cuales es la preferencia por el periodo largo de la frase, repleta de cláusulas subordinadas, que el autor, probablemente algún secretario del monarca, ${ }^{38}$ elaboró con prudencia para que el texto se leyera con fluidez. Otro rasgo estilístico notable es la presencia de dobletes de términos sinónimos o casi sinónimos; se trata por lo general de adjetivos, aunque también los hay de sustantivos y verbos. ${ }^{39}$ En ocasiones la cadencia de la frase se consigue enumerando tres

adelante: «No hi ha cap discurs polític d'aquest període que es pugui comparar amb el pronunciat pel rei Martí. Per trobar una peça de la mateixa categoria ens hem de traslladar al regnat d'Alfons el Magnànim i llegir la resposta del cardenal Margarit a Joan, rei de Navarra com a lloctinent del seu germà, en el qual recordà la cèlebre oració del 1406» (1984: 274-275). Martín de Riquer, por su parte, indica que su estructura es muy parecida a la de los discursos de Pedro el Ceremonioso o a la de los sermones de sant Vicent Ferrer, «car la matèria s’hi va exposant a base de distincions o parts enunciades amb homoiotelèuton» (1980: II, 341-342).

38 Rubió i Balaguer considera, en referencia al parlamento de 1406 de Martín I, «que no fou el rei en persona el redactor de la impressionant peça oratòria, sinó algun funcionari de la seva cancelleria» (1984: 274). Para Riquer, «és molt possible que [...], com la majoria dels discursos dels nostres reis [...], fos redactada per algun funcionari de la Cancelleria, o, potser millor, per un grup de funcionaris sota la direcció del reì (1980: II, 344). Señala Pedro M. Cátedra (1985-1986: 25), a propósito de la oratoria política cuatrocentista castellana: «Juan II [de Castilla] gustaba de la proposición de cortes en forma de sermón, pero [..., incapaz de aplicarse él mismo, daba la palabra a un clérigo». Así había ocurrido en las cortes de Ávila de 1420 y ocurrirá de nuevo en las vallisoletanas de 1425, relatadas brevemente en la crónica de Álvar García. En este caso «las dos horas de sermón quedan reducidas a veinte líneas. No es desde luego el cuidado que ponían en Aragón por preservar la copia auténtica en el proceso de cortes».

39 Adjetivos (y participios): necessaria e convenible (1. 5); perteneciente e devida (1. 8); elevados e ensuperbecidos (1. 26); muchas e excessas (1. 26); regido e agabellado (1. 36); pravos e malvados (1. 49); instada e suplicada (1. 52); turbados e maravillados (1. 57-58); feo e detestable (1. 58); perversos e infides (1. 67-68); instado e consejado (1. 97); iniquos e malos (1. 99); fuertes e continuos (1. 110-111); reparados e satisfechos (1. 136); santa e honesta (1. 162); gastados e consumidos (1. 178); mostrado ni preparado (1. 186); opugnada e expellida (1. 188); leales e fieles (194-195); dura e superba (1. 219); necessarias et oportunas (1. 230); perteneciente e devido (1. 246-247); buena e clara (1. 249); derramado [la sangre] e 
David Guixeras \& Agustín Rubio Vela. El parlamento de Juan II ante las cortes generales de Monzón (1469). Una pequeña crónica autobiográfica en lengua castellanoaragonesa

palabras de la misma categoría gramatical. Por lo general estas trimembraciones nacen de la simple yuxtaposición de vocablos («consejando, instando e requiryendo», 1. 95; «drecho, razón e ahun lealtat», 1. 133; «cautelas, stucias e falsedades», 1. 147; «rogados, exortados e requeridos», 1. 166; «trabajos, periglos e infortunios», 1. 177; «haver, quitar e poner», 1. 214; «rogamos, encargamos e exortamos», 1. 225), pero en la última parte de la pieza encontramos enumeraciones encajadas en una estructura más amplia que proporciona un ritmo de lectura pausado: «havéys desemparado vuestras casas, perdido vuestros patrimonios e abandonado vuestros parientes, mujeres e fijos» (1. 197-199); «Nos havemos a vossotros fallado en fidelitat vassallos, en las subvenciones amigos e en obediencia fijos» (1. 202-203); «havemos ganado Lérida, tomado Cervera, cobrado Tortosa» (1. 203-204); «los tantos vencimientos, las tantas ofensas con tantos derramamientos de sangre» (1. 220-221). El adjetivo antepuesto al sustantivo y el desplazamiento del verbo al término de la frase —verbo in fondo-, recursos habituales en los textos latinizantes, son otras de las características retóricas que encontramos a lo largo del parlamento de Juan II.

Hallamos también una tendencia a la frase lenta y cargada. En la retardación del final, que se produce a menudo a través de incisos más o menos largos, unidos a series de oraciones subordinadas, reconocemos un atisbo de sintaxis latinizante; no documentamos, en cambio, ninguna oración de infinitivo, uno de los rasgos más evidentes de imitación de la sintaxis latina, especialmente de la ciceroniana.

Las líneas que abren y cierran los textos de aparato siempre se escribieron con un cuidado especial. Era éste - y lo es todavía - uno de los principios básicos de la retórica y de la oratoria. En el breve proemio del parlamento de Juan II (1. 1-6) parece haberse buscado la distribución acentual correspondiente al cursus planus latino:

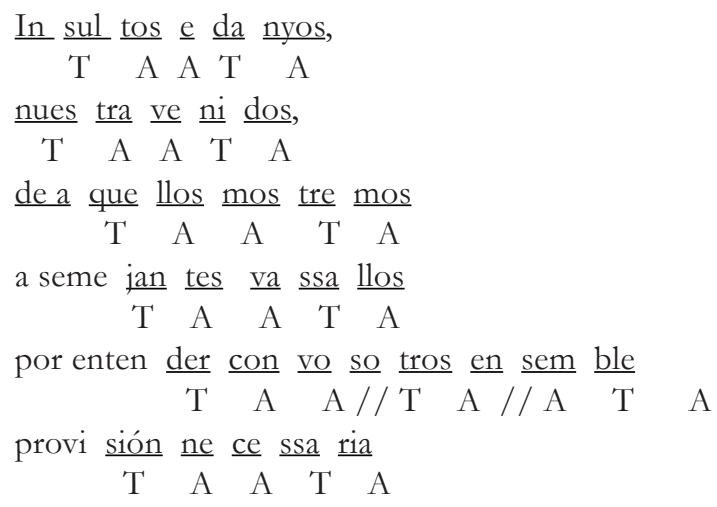

ofrecido [las vidas] (1. 195-196). Sustantivos: insultos e danyos (1. 1); benignidat e amor (1. 3); senyoríos e regnos (1. 8); voluntat e obediencia (1. 8); agravios e injusticias (1. 9); ruina e perdición (1. 17); intervención e consejo (1. 23); palabras e razones (1. 40); benignidat e complazimientos (1. 70); inhumanidat e crueza (1. 112); agravios o sinrazones (1. 127128); pacificación e concordia (1. 167); infidelidat e maldat (1. 194); sinceritat e bondat (1. 194); stado e vida (1. 210); emolumentos e rentas (1. 242); honor e virtud (1. 245); tranquilidat e reposo (1. 254); renombre e fama (1. 255). Verbos: excitar hi albolotar (1. 32); pudiessen e ossasen (1. 48-49); preparar e mover (1. 92); instando e requiryendo (1. 95); castigar e punir (1. 96); publicaron e pregonaron (1. 151); destruir e gastar (1. 172-173); trabajemos e entendamos (1. 207). 
David Guixeras \& Agustín Rubio Vela. El parlamento de Juan II ante las cortes generales de Monzón (1469). Una pequeña crónica autobiográfica en lengua castellanoaragonesa

En las últimas palabras del exordio observamos la tendencia a acabar las cláusulas con la serie TA:

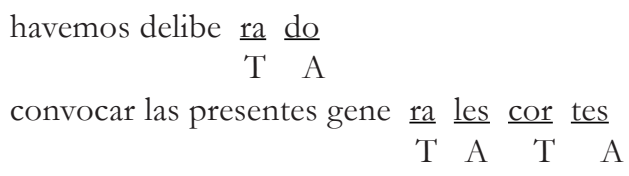

Por otro lado, la frase que cierra el parlamento recupera la distribución acentual del cursus planus:

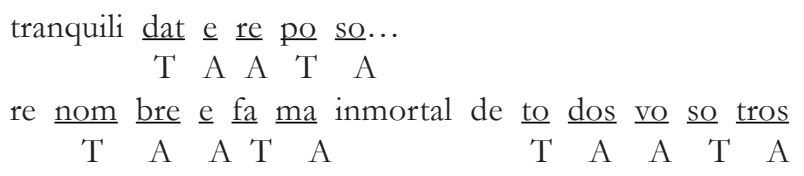

El análisis retórico demuestra la existencia de algunos elementos anafóricos. Destaca el interés por enfatizar, mediante este recurso, el contraste entre los posesivos de primera y segunda persona, o de primera y tercera. Veamos a continuación algunos ejemplos, con algo de contexto para que se aprecie el juego retórico: el príncipe don Carlos, fijo nuestro, tractava con algunos adversarios nuestros en Castilla algunas cosas, contrariando al stado nuestro (1. 13-15); deliberamos, con el consejo de algunos principales de nuestros regnos, por evitar los tales inconvenientes, detener la persona del dicho príncipe, a fin que, con la detención de aquell... (1. 22-23); diminuyendo la nuestra, pudiessen agumentar la potestat suya (1. 34); recogidos dentro la Fuerça Vieja de la dicha ciudat, fueron luego por los dichos adversarios sitiados (1. 109); restamos no poco congoxados por ver en tanta presura las personas a nos tanto caras (1.122); viniendo nos a Balaguer a fin de socorrer nuestra mujer e fijo e a tantos buenos con ellos encerrados, socorridos en este medio por la gente francesa, fueron liberados de sus crueles manos (1. 142-143); sin dexando aparte toda natura de plazeres, sin perdonar a nuestra edat nin guardar a la real preheminencia, havemos ofrecido la persona a qualesquiere trabajos, periglos e infortunios sin que en verdat no havemos perdonado a los bienes (1. 175-177); no solamente nos, mas los descendientes nuestros quedan en obligación de vosotros (1. 190); dexamos al arbitrio de vosotros, en manos e poder de los quales, encomendando el stado nuestro, vos recordamos que entre vuestras deliberaciones queráys considerar aquello que al honor e virtud vuestra conviene, e guardar aquello que a la nuestra real dignidat es perteneciente e devido (1. 243-246).

Indicaremos finalmente algunos ejemplos de quiasmo: aquesto molestamente sofriendo, $\underline{\text { cayendo }}$ en mortal dolencia (1. 85); iniquos e malos conceptos al fin deseado (1. 99); sobrino nuestro ... nuestro

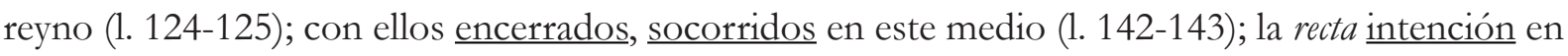
las voluntades conformes (1. 239-240). 
David Guixeras \& Agustín Rubio Vela. El parlamento de Juan II ante las cortes generales de Monzón (1469). Una pequeña crónica autobiográfica en lengua castellanoaragonesa

\subsection{Análisis lingüístico}

El parlamento de 1469 es una de las escasas muestras conservadas del aragonés tardío, que se caracteriza por un elevado grado de castellanización. ${ }^{40}$ Para analizarlo reproduciremos, en negrilla, los apartados del inventario de Dawn E. Prince (2007) en su estudio del Libro del trasoro, traducción aragonesa de finales del siglo XIV, y lo completaremos con ejemplos procedentes del discurso de Juan II —indicamos en este caso el número de línea con referencia a nuestra edición- y, a título complementario, de la documentación publicada por Gifford y Hodcrof (1966), Coloma Lleal (1997) y Manuel Alvar (1978). Veremos de este modo hasta qué punto se han producido variaciones significativas entre el Libro del trasoro y los textos de la segunda mitad del siglo XV. También utilizaremos el Diccionario etimológico castellano e hispánico, de Corominas y Pascual (1997), así como la edición de Guardiola Alcover (1998) del Rams de Flores o Libro de actoridades de Juan Fernández de Heredia.

\subsubsection{Ortografía}

\section{$\mathrm{c}>\mathrm{qu}, \mathrm{g}>\mathrm{gu}$}

longua (1. 9), iniquos (1. 99, 1. 108), lleguados (1. 99), iniqua (1. 213)

de muchos tiempos aqua (Lleal 1997: 132), los fechos de aqua, las cosas de aqua (ibid., 141)

La única ocurrencia del adverbio aqua en Gifford y Hodcrof (1966) corresponde a un texto aragonés (doc. 121).

\section{la palatal fricativa sonora se escribe -i- en el interior de palabra}

ayuntados (1. 23), adiutor (1. 156), subjectos (1. 201), trabayan (1. 217)

no y haia falta (Lleal 1997: 130)

40 Agradecemos al profesor Germà Colón, al que visitamos en su casa de Barcelona el 9 de julio de 2015, la atenta lectura que realizó del texto del parlamento. Su conclusión fue categórica: se trata de un ejemplo de aragonés tardío y no de castellano con aragonesismos. El profesor Vicente Lagüéns, de la Universidad de Zaragoza, ha coincidido en esta conclusión tras realizar un análisis meticuloso del texto y del estudio, enriquecido gracias a sus generosas orientaciones filológicas y bibliográficas, merecedoras de nuestra gratitud. 
David Guixeras \& Agustín Rubio Vela. El parlamento de Juan II ante las cortes generales de Monzón (1469). Una pequeña crónica autobiográfica en lengua castellanoaragonesa

\section{vacilación en la representación de la palatal nasal: $\mathrm{nn}, \mathrm{nj}, \mathrm{yn}, \mathrm{n}, \mathrm{ny}{ }^{41}$}

En nuestro texto encontramos de manera prácticamente exclusiva la grafía $n y$; solo en un caso (dona) la palatal nasal se representa con la grafía $n$.

danyos (1. 1), senyor (1. 6, passim), senyoríos (1. 10), se desdenyavan (1. 29), dona (1. 60), senyoría (1. 78, passim), Catalunya (1. 78), anyos (1. 88), ninyo (1.114), desdenyando (1.132), aconpanyado (1. 189), acompanyado (1. 208), pequenyas (1.241)

\section{simplificación gráfica -rr-> -r-}

virei (1. 61; A: bisrei; C: visrey) ${ }^{42}$

\section{$\mathrm{h}$ antietimológica}

Se trata de la $h$ expletiva inicial a la que se refiere Alvar (1978: 149). El adverbio bi es el único ejemplo de esta característica gráfica que encontramos en el discurso de Juan II.

Es común, en cambio, la $h$ intervocálica: ${ }^{43}$

hi (1. 59, 134) ahunque (1. 80, 180), provehido (1. 90), ahun (1. 59, 125, 133, 163, 213, 216), preheminencia (1. 176), lahor (1. 205), trahido (1. 213), preheminentes (1. 215), trahe (1. 240)

\section{grafías latinizadas y pseudolatinizadas (ch, $11, \mathrm{ph}, \mathrm{ps}, \mathrm{th})$}

Barchinona (1. 91), cathalanes (1. 193), Cathalunya (1. 205)

41 En los «Documentos de Jaca (1362-1502)», Alvar encuentra solo las grafías nny, ny como equivalentes a la ñ castellana. Puede tratarse de influencia catalana. Los documentos 96 y 106 de la antología de Gifford y Hodcrof (1966: 129), que corresponden respectivamente a los Estatutos de buen gobierno de la ciudad de Jaca (¿1238?) y a la Disposición del Fuero de Jaca (¿primera mitad del siglo XIV?), reflejan claramente el «influjo del catalán, o quizá de una koiné catalano-occitana, muy usada, según Corominas, no sólo en Aragón sino también en Navarra en la segunda mitad del siglo XIII y en el XIV».

42 En la carta 136 del repertorio Lleal (1997), de 1465, leemos también «Visrey».

43 En el corpus examinado por Arnal y Enguita (1993: 55) aparecen tanto la $b$ expletiva o adventicia en posición inicial de palabra (babundantment, heras, hir, hobra, honze, hosado, hotro, hun, buna) como en su interior (cahera, exhigir, loharon, thomar). 
David Guixeras \& Agustín Rubio Vela. El parlamento de Juan II ante las cortes generales de Monzón (1469). Una pequeña crónica autobiográfica en lengua castellanoaragonesa

Calathayut (Lleal 1997: 131)

Entre los 200 documentos cancillerescos del siglo XV (1412-1498) que publica Lleal (1997), 9 llevan la forma Barcelona, 43, Barchelona, y 11, Barchinone.

\subsubsection{Vocales tónicas}

\section{Ě >jé tónica; influencia catalana en numerosos ejemplos de ě no diptongada}

Son inexistentes los ejemplos de diptongación de la e y la $o$ tónicas del latín vulgar seguidas de yod. Este rasgo, de lo más corriente en el aragonés de finales del siglo XIV — también lo encontramos, por ejemplo, en el Rams de Flores de Juan Fernández de Heredia (Guardiola 1998: 59)—, fue perdiendo vitalidad a lo largo del XV.

requiryendo (1. 95; BC: requirendo)

manifestos (1. 1), vintisiete (1. 35), ${ }^{44}$ seyscintas (1. 137; C: siscentas)

vinticinquo (Lleal 1997: 129), sixanta (ibid.: 126), xixanta (ibid., 133)

diptongación ante yod; restauración de la vocal no diptongada por influencia castellana

lat. - ěllu->-iello

wé-; eventualmente, oclusión completa con grafía gue-

No hallamos ejemplos de estos fenómenos en el discurso de Juan II.

\subsubsection{Vocales átonas}

alto grado de inestabilidad; fluctuaciones comunes: e-i / o-u / e-a / e-o

novidades (1. 33), disposimos (1. 45, 134), proferiendo (1. 63), sofriendo (1. 84), artellería (1. 110, 113), consentieron (1. 114), podiera (1. 123), sentiendo (1. 135), mesmos (1. 172), recebido (1. 191)

44 Se trata de la fusión de dos vocales iguales en una única vocal, al estar en posición de hiato: vīginti > vint. (Alvar 1978: 157). 
David Guixeras \& Agustín Rubio Vela. El parlamento de Juan II ante las cortes generales de Monzón (1469). Una pequeña crónica autobiográfica en lengua castellanoaragonesa

\subsubsection{Vocales finales}

La apócope de las vocales finales es un rasgo propio del aragonés que empezará a fluctuar con la presión castellana. Gifford y Hodcrof (1966: 124) no documentan hasta la segunda mitad del siglo $\mathrm{XV}$ la reaparición de la $-\mathrm{e}$ final tras los grupos $-\mathrm{rt}$ y $-\mathrm{nt}$. Alvar ofrece la casuística completa de la pérdida de las $e$ y las $o$ finales (1978: 153-155). En el parlamento de Juan II hallamos casos de pérdida de la e tras el grupo de nasal y dental end; de la pérdida, más generalizada, de esta misma vocal en los participios de presente y en los adverbios en - ment; de caída de la e tras vibrante seguida de dental y de ausencia de la $o$ tras el grupo consonántico - nt (segunt, segund).

comodament (1. 44), part (1. 204)

scientment, de continent, segund (Lleal 1997: 125), bastant poder (ibid., 126), de nuestra part (ibid., 128), etc.

\subsubsection{Vocales protéticas}

\section{falta de vocal protética ante inicial de palabra s- + consonante}

stado (1. 15, 25, 194, 210, 244), stando (1. 53, 107), scondidamente (1. 57), scándalos (1. 92), stavan (1. 113), spada (1. 120), scudos (1. 138), stucias (1. 147), sperar (1. 208), scusado (1. 230), sfuerço (1. 234)

stadas, scientment, sperado (Lleal 1997: 125), se sdevendra (ibid., 133), spital (ibid.)

Según Alvar (1978: 159), la desaparición inicial de la e-ante s- líquida es un fenómeno típico del aragonés del siglo XV que «pudiera obedecer a un afán en muchos casos etimologista».

\subsubsection{Apóstrofe}

\section{es ocasional con el artículo el / la y la preposición de.}

D’Urrea (1. 62), d'ellos (1. 101, 104, 160), d'Aragón (1. 237)

d ·ellos (Lleal 1997: 126), d essa nuestra ciudat (ibid., 131), d ·ello (ibid., 141)

d'ellos (Gifford y Hodcrof 1966: doc. 95)

Uno de los rasgos comunes al español de Navarra y Aragón, según Gifford y Hodcrof (1966: 124), es precisamente la «tendencia a elidir de, que, etc. ante palabra que empieza con vocal (dalli, daqui). 
David Guixeras \& Agustín Rubio Vela. El parlamento de Juan II ante las cortes generales de Monzón (1469). Una pequeña crónica autobiográfica en lengua castellanoaragonesa

\subsubsection{Consonantes iniciales}

las consonantes agrupadas PL-, FL-, CL- se conservan.

La conservación de los grupos iniciales latinos CL- y PL- es uno de los cuatro rasgos comunes a los textos de Navarra y Aragón, inexistentes en castellano, que señalan Gifford y Hodcrof (1966: 123-124). No lo documentamos, sin embargo, en el parlamento de Juan II.

\section{la F- inicial latina se mantiene.}

Se trata un fenómeno generalizado hasta finales de la Edad Media, por lo que solo relacionaremos los ejemplos presentes en el parlamento de Juan II.

fijo (1. 13, passim), fazer (1. 47, 164), de fecho (1. 34-35, 51, 123-124), se fallavan (1. 56, 101), fechas (1. 75), fizieron (1. 96), se fazía (1. 102), fazían (1. 112), fasta (1. 114, 137, 235), fruita (1. 114), fallándose (1. 154), fecho (1. 169), fallado (1. 202), fechos (1. 221)

inicial G + e/i y J->ž

No encontramos ejemplos de este rasgo aragonés en el discurso de Juan II.

\subsubsection{Consonantes medias}

-C(')T-, -ULT->jt. La solución castellana, -C(')T->ĉ, será la predominante a finales del siglo XV.

El discurso contiene la vacilación $t /$ ch, de lo más habitual en los textos aragoneses de la Baja Edad Media.

dicha (1. 109; BC: dita)

dicho... ditos (Lleal 1997: 126), dichas (ibid., 129), dito Canonge (ibid., 132), dita... dichas... sobredito... ditos... ditas... ditas... dicho... ditas... dicho (ibid., 133), etc. 
David Guixeras \& Agustín Rubio Vela. El parlamento de Juan II ante las cortes generales de Monzón (1469). Una pequeña crónica autobiográfica en lengua castellanoaragonesa

grupos latinos intervocálicos -LY-, -C’L-, -T'L->1j

rebellión (1. 149)

\section{conservación de la -D- latina}

No hallamos ningún ejemplo en nuestro discurso. Alvar (1978: 161) presenta cinco casos de un fenómeno que en el aragonés del siglo XIV era generalizado: possedir, judicio, prouedimos, sodes, perjudicio.

prejudicio (Lleal 1997: 130)

\section{palatalización del grupo latino -SC->š}

Las ocurrencias de la grafía $x$ que documentamos en el parlamento de Juan II no corresponden a este fenómeno, según el cual la $s$ apical se convierte, por atracción de la consonante siguiente, en predorsal alveolar y después en prepalatal. ${ }^{45}$ Se trata de casos paralelos a faxo, axadas o axadones, que resultan de la combinación de consonante seguida de yod (SCÝ) (ibid., 165).

enbaxada (1. 39), embaxadores (1. 45, 48, 54, 129, 131), sexanta (1. 47), executar (1. 49), dexándole (1. 84), dexassen (1. 116), dixesen (1. 117, 125), enbaxadores (1. 124), exortándolos (1. 161), exortados (1. 166), dexando (1. 174), exemplo (1. 184), exortamos (1. 225), exercicio (1. 231), dexamos (1. 243)

executado (Lleal 1997: 126), vos dixiessemos (ibid., documento de 1477), embaxador (ibid., 141), exequtuavamos (ibid., 142).

\subsubsection{Finales secundarias}

las consonantes medias convertidas en finales tienden a permanecer intactas, con la excepción de la intervocálica -d- > -t-.

benignidat (1. 3, 41, 70), voluntat (1. 8, 89), potestat (1. 29, 34, 37), virtut (1. 35, 245 [virtud], 252), ciudat $(1.36,54,105,109)$, comodament (1. 44), perversidat (1. 80), edat (1. 88, 175), segunt (1. 90, 97 [segund C], 129 [segund C]), inhumanidat (1. 112), maldat (1. 146), malignidat (1. 171), verdat (1. 177, 200), lealdat (1. 185), crueldat (1. 211), promptitut (1. 229), bondat (1. 247), fidelidat (1. 252), tranquilidat (1.254)

45 Los ejemplos que aduce Alvar (1978: 162) son pertenexientes, paxer, naxeran, fenexen. 
David Guixeras \& Agustín Rubio Vela. El parlamento de Juan II ante las cortes generales de Monzón (1469). Una pequeña crónica autobiográfica en lengua castellanoaragonesa

\subsubsection{Morfología}

los artículos definidos son el/los, la/las; en aragonés antiguo, el artículo masculino singular era lo (forma disimilada en las locuciones la uno / la otro)

\section{posesivos: lur/lur>ILLORUM}

Ni en la documentación cancilleresca publicada por Coloma Lleal ni en el parlamento de Juan II hallamos ocurrencia alguna de lur/llur, adjetivo posesivo de tercera personal del plural.

\section{demostrativos: est, aquest, aquell}

aquestos regnos (1. 19), detención de aquell (1. 23), aqueste stado (1. 25), de aquesto (1. 33, 173), aqueste consejo (1.39), en aquesto (1.53,59), aquesto molestamente sofriendo (1. 84), aquesto fue instado (1. 97), embiaron aquell (1. 105), aquestas cosas (1. 121), aqueste discurso (1. 165), aquestos tiempos (1. 186), de aquellas (1. 206, 234), aquello (1. 245, 246, 251)

aquesto (Lleal 1997: 125, 126, 141), aquell (ibid., 131)

La forma aquesto aparece documentada en textos castellanos, asturianoleoneses, navarros y aragoneses (Gifford y Hodcrof 1966: doc. 13, 42, 82, 102, 119); en cambio, encontramos aquell solo en documentos navarros $(83,86)$ y aragoneses $(111,112)$.

pronombres relativos: qui para referirse a los hombres; que, a las mujeres y los objetos.

formación del plural: es rasgo genuinamente aragonés la añadidura de $-\mathrm{s}$ al lexema en caso de apócope.

No encontramos ejemplos de estos dos fenómenos en el discurso de Juan II.

\subsubsection{Conjugaciones verbales}

preferencia por los verbos en -ir, en contraste con el castellano.

No hallamos ningún ejemplo en el discurso de Juan II. 
David Guixeras \& Agustín Rubio Vela. El parlamento de Juan II ante las cortes generales de Monzón (1469). Una pequeña crónica autobiográfica en lengua castellanoaragonesa

infijo incoativo: no suele aparecer en el infinitivo aragonés, al contrario que en castellano, pero sigue los criterios de preferencia del catalán para las formas conjugadas.

aborresciendo (1. 158), peresca (1. 249)

\subsubsection{Presente}

segunda persona del plural: -TIS>-z; en español antiguo, -TIS>-des

\subsubsection{Imperfecto}

la desinencia castellanizante -ié en contraste con la aragonesa -ía

\subsubsection{Imperativo}

segunda persona del plural: conserva la consonante sorda latina -T- como desinencia

Ninguno de estos rasgos aparece documentado en nuestro parlamento.

\subsubsection{Adverbios}

temporales: agora, ante(s), apres, ara, aun, cras, dantes, de(s)pues, encara, hoy, jamas, las oras, luego, lugo, nunca, pues, siempre...

espaciales: alla, aquí, allí, çaga, çerca, davant, defuera, delant, dentro, derredor, desus, ensemble... ensemble (1. 4, 96,120, 203), ensenble (1. 54). Este adverbio cuenta con diez ocurrencias en los textos publicados por Lleal (1997: 256). Corominas y Pascual (1997: II, 640, s. v. ensamblar) documentan a partir de 1212 «el galicismo ensemble 'juntamente’ en la Rioja y Aragón».

\subsubsection{Preposiciones}

a, açaga, ad, apres, çaga, con, contra, de, devant, denant...

La preposición enta (1. 251), genuinamente aragonesa, tiene en nuestro texto el valor de «alrededor, hacia», distinto del más habitual «hasta» $\mathrm{O}$ «hasta que». Aunque bien pudiera tratarse de un error de copia por ante (de hecho, el manuscrito C lee anta), el criterio de economía nos aconseja editar 
David Guixeras \& Agustín Rubio Vela. El parlamento de Juan II ante las cortes generales de Monzón (1469). Una pequeña crónica autobiográfica en lengua castellanoaragonesa

aquella preposición. Germà Colón cita una carta de Juan II a la reina, de 1461, en la que aparece la preposición enta: «E no dubdamos que los catalanes como fidelíssimos súbditos vassallos nuestros no riendan enta nós, siempre que mester sia, el deudo que han rendido con mucha virtud e lealtad a los otros reyes d'Aragón» (1989: 263, nota 95).

En los 200 documentos cancillerescos publicados por Coloma Lleal, la preposición enta cuenta con una sola ocurrencia, mientras que ante aparece en nueve ocasiones (1997: 258).

Corominas y Pascual consideran enta una preposición del aragonés antiguo, muy bien representada en «autores y textos aragoneses de los ss. XIV-XVI» (1997: II, 604).

\subsubsection{Sintaxis}

Cabe señalar tres peculiaridades sintáticas aragonesas:

complementos adverbiales procedentes de los latinos INDE e IBI: ende/'nde (aragonés/ castellano) o en/ne, hi/y/i (influencia catalana).

so aquella color tenían hi el consejo e las armas (1. 74-75)

El adverbio hi presenta 23 ocurrencias en la documentación publicada por Coloma Lleal (1997: 255)

Es rasgo aragonés el uso de y (< IBI) como CI de persona (Gifford y Hodcrof 1966: 124).

negaciones reforzadas: no... gayre, no... pas, no... pont

Este rasgo no aparece en el parlamento de Juan II, aunque tal vez algo tiene de negación reforzada la expresión no... punto en el fragmento «las cosas fechas por nos no conferían punto con la intención suya» (1. 75-76).

\section{concordancia del participio pasado con el CD de los verbos transitivos}

havemos tantos gastados e consumidos (1.178)

Respecto a este fenómeno, Germà Colón ha señalado que «la concordancia del participio con el complemento se pierde pronto en español; en catalán perdura largo tiempo [...] Los documentos 
David Guixeras \& Agustín Rubio Vela. El parlamento de Juan II ante las cortes generales de Monzón (1469). Una pequeña crónica autobiográfica en lengua castellanoaragonesa

nuestros nos la señalan en aragonés hasta muy tarde, sin que falten atisbos de neutralización ya temprana» (1989: 262).

$\mathrm{Al}$ margen de los rasgos inventariados por Prince (2007), encontramos en el parlamento de Juan II otras cuatro características del aragonés medieval recogidas en la antología de Gifford y Hodcrof (1966). En primer lugar, la posibilidad de que la grafía Ç aparezca en final de palabra (1. 174 y 227: paç). En segundo lugar, la expresión adverbial la hora, con el significado de 'entonces', en «la hora que vieron por la detención de nuestro fijo algún tanto comovidos los pueblos» (1. 3132). En tercer lugar, la estructura artículo definido + sustantivo + adjetivo posesivo, que aparece en diez ocasiones. ${ }^{46}$ Finalmente, la combinación de dos adverbios de modo de los cuales solo el primero lleva la terminación -ment, aunque en este caso se trata del equivalente castellano: «drechamente e concordable» (1.238).

Añadiremos, para acabar, otros tres ejemplos de vocabulario típicamente aragonés. En primer lugar, la conjunción causal car (1. 181, 195, 231, 239), que «figura sólo en textos aragoneses y en parte es catalanismo [...] Lo normal en todos los dialectos del español medieval es CA» (Corominas y Pascual 1997: I, 839). En segundo lugar, el gerundio posposando (1. 197), que en la antología de Coloma Lleal (1997: 247-255) aparece en diversas ocasiones. ${ }^{47}$ Finalmente, el sustantivo periglo (1. 177: periglos), que aparece documentado en dos ocasiones entre los documentos cancillerescos publicados por la autora antes citada (1997: 234). Lo encontramos también en el documento 117, aragonés, de la antología Gifford y Hodcrof (1966). Se trata de un semicultismo en el que se mantiene la forma etimológica (Alvar 1978: 166).

\section{Nuestra edición}

En la edición se ha procurado reconstruir el texto original del parlamento del rey, a partir de las tres copias coetáneas llegadas a nuestras manos, que llamaremos A, B y C. Las dos primeras se encuentran en la serie Processos de Corts del Archivo Municipal de Valencia (A: signatura yy-23; B: signatura yy-24, ff. 6r-9r), y la tercera en el Archivo de la Corona de Aragón (Generalitat, sèrie N, vol. 987, ff. 41r-45v). Aunque con algunas ligeras variaciones, se trata de un mismo documento: el discurso que el rey pronunció ante las cortes generales de la Corona de Aragón el 13 de noviembre de 1469. Tal vez por haber sido copiado por escribanos que habitualmente redactaban en catalán, contienen confusiones y errores propios de quienes manejan una lengua con la que no están

46 1. 15: «al stado nuestro»; 1. 94, 113: «los senyores suyos»; 1. 130: «la intención suya»; 1. 133-134: «los ánimos suyos»; 1. 146: «la maldat suya»; 1. 171: «la malignidat suya»; 1. 183: «el stado nuestro»; 1. 196: «del stado nuestro»; 1. 244: «el stado nuestro»; 1. 245: «al honor e virtud vuestra».

47 Lleal documenta tanto el verbo poner (67 ocurrencias) como la forma posar (18 ocurrencias) y algunos verbos derivados de ésta: posposar (6 ocurrencias), deposar (4), exposar (3), imposar (3), reposar (3), interposar (3). 
David Guixeras \& Agustín Rubio Vela. El parlamento de Juan II ante las cortes generales de Monzón (1469). Una pequeña crónica autobiográfica en lengua castellanoaragonesa

familiarizados. Esto, que confiere al documento (a los documentos) un especial interés lingüístico, aumenta la complejidad de una edición como ésta, que pretende reconstruir el discurso en su versión más próxima a la original mediante el estudio y cotejo de las tres copias, ninguna perfecta. En el cuerpo del documento nos hemos quedado con las palabras en apariencia más fieles, y en nota a pie de página hemos señalado solo las variantes que hemos considerado significativas; no las simples modificaciones de carácter ortográfico, que hemos considerado irrelevantes para nuestro propósito.

La transcripción es fiel a los originales, si bien, como es habitual en las ediciones científicas de textos medievales, se ha acentuado el texto para su mejor comprensión; también se han separado o unido las palabras de acuerdo con las normas ortográficas actuales del castellano (p. ej., portanto: por tanto; como quiera: comoquiera); se ha usado el apóstrofo (Daragon: d’Aragón), ocasionalmente el punto volado (quel: que l) y regularizado el uso de i y j, y el de u y v (deujda: devida; trabaio: trabajo), así como el de mayúsculas y minúsculas (Rey de francia: rey de Francia). Transcribimos ç cuando en el original figura, por descuido del escribano, una c (lancas: lanças), y f simple cuando aparece doble a comienzos de la palabra: (ffranceses: franceses). Las abreviaturas están desarrolladas (R e S: rey e senyor). Las tachaduras y añadidos en interlineado sólo se señalan en casos significativos. La puntación se ha realizado con un criterio fidelidad y claridad, por lo que los signos que aparecen en los originales sólo se han tenido en cuenta con carácter orientativo. 
David Guixeras \& Agustín Rubio Vela. El parlamento de Juan II ante las cortes generales de Monzón (1469). Una pequeña crónica autobiográfica en lengua castellanoaragonesa

\section{Bibliografía}

Albert, Ricard, y Gassiot, Joan, eds. (1928) Parlaments a les Corts Catalanes, Barcelona, Barcino.

Alcoberro, Agustí, ed. (1997) Pere Miquel Carbonell: Cròniques d'Espanya, Barcelona, Barcino, 2 vols.

Alvar, Manuel (1978) Estudios sobre el dialecto aragonés, vol. II., Zaragoza, Institución «Fernando el Católico».

Arnal, Ma Luisa, y Enguita, J. Ma (1993) «Aragonés y castellano en el ocaso de la Edad Media», Aragón en la Edad Media, 10, pp. 51-84.

Bofarull y de Sartorio, M., ed. (1858-1864) Colección de documentos inéditos del Archivo General de la Corona de Aragón, XIV-XXVI: Levantamiento y guerra de Cataluña en tiempos de Juan II. Documentos relativos á aquellos sucesos, [CoDoInACA, XIV-XXVI] Barcelona, 13 vol.

Calmette, Joseph (1903) Louis XI, Jean II et la révolution catalane (1461-1473), Toulouse-París.

Carrasco Manchado, A. I. (2000) Discurso político y propaganda en la corte de los Reyes Católicos (14741482), Tesis doctoral dirigida por J. M. Nieto Soria, Madrid, Universidad Complutense.

Carriazo, J. de M., ed. (1941), Memorial de diversas hazañas. Crónica de Enrique IV, ordenada por mosén Diego de Valera, Madrid, Espasa-Calpe.

Cátedra, Pedro M. (1985-1986) «Acerca del sermón político en la España medieval. (A propósito del discurso de Martín el Humano en las cortes de Zaragoza de 1398», Boletín de la Real Academia de Buenas Letras de Barcelona, VI, pp. 17-47.

Cawsey, Suzanne F. (2008) Reialesa i propaganda. L'eloqüència reial i la Corona d'Aragó, c. 1200-1450, València, PUV.

Coll Juliá, Nuria (1953) Doña Juana Enríquez, lugarteniente real en Cataluña (1461-1468), Madrid, CSIC, 2 vols.

Colón, G. (1989) «El aragonés cancilleresco: sociología de un idioma», en El español y el catalán, juntos y en contraste, Barcelona, Ariel, pp. 237-270.

Coroleu e Inglada, J., y Pella y Forgas, J. (1876) Las cortes catalanas. Estudio jurídico y comparativo de su organización y reseña analitica de todas sus legislaturas, Barcelona, Imprenta de la revista histórica latina, $2^{\mathrm{a}}$ ed.

Corominas, Joan [con la colaboración de Pascual, J. A.] (1997) Diccionario crítico etimológico castellano e hispánico, Madrid, Gredos, 6 vols.

Desdevises du Dezert, G. (1889) Don Carlos d'Aragon, prince de Viane. Étude sur l'Espagne du nord au XVe siècle, París, Armand Colin.

Gifford D. J., y Hodcroft, F. W. (1966) Textos lingüisticos del medioevo español, Oxford, The Dolphin Book (2a ed.). 
David Guixeras \& Agustín Rubio Vela. El parlamento de Juan II ante las cortes generales de Monzón (1469). Una pequeña crónica autobiográfica en lengua castellanoaragonesa

Guardiola, Conrado, ed. (1998) Rams de flors o Libro de actoridades. Obra compilada bajo la protección de Juan Fernández de Heredia, Maestre de la Orden del Hospital de San Juan de Jerusalén (edición del ms. de la Real Biblioteca de El Escorial Z-I-2), Zaragoza, Institución «Fernando el Católico» (CSIC).

Lleal, Coloma (1997) El castellano del siglo XV en la Corona de Aragón, Zaragoza, Institución «Fernando el Católico», Fuentes Históricas Aragonesas, 26.

Llorca, Fernando (s. d.) Sublevación del infante don Jaime de Aragón, seguida de la de su bijo del mismo nombre (1462-1477), Valencia, Talleres Prometeo.

Martínez Aloy, J. (1930) La Diputación de la Generalidad del Reino de Valencia, Valencia.

Martínez Ferrando, J. E. (1942) Tragedia del insigne condestable don Pedro de Portugal, Madrid, C.S.I.C.

Menéndez Pidal, R., dir. (1982) Historia de España, vol. XV. Los Trastámaras de Castilla y Aragón en el siglo XV. Juan II y Enrique IV de Castilla (1407-1474). El Compromiso de Caspe, Fernando I, Alfonso V y Juan II de Aragón (1410-1479), Madrid, Espasa-Calpe, $3^{\mathrm{a}}$ ed.

Miranda Menacho, Vera-Cruz (2011) El príncipe de Viana en la Corona de Aragón (1457-1461). Tesis doctoral dirigida por Roser Salicrú Lluch y Eloísa Ramírez Vaquero, Universitat de Barcelona.

Muxella Prat, Imma (2000-2001) La Terra en guerra. L'acció de les institucions durant el regnat de Renat d'Anjou (1466-1472). Tesis doctoral dirigida per Eva Serra i Puig, Universitat de Barcelona.

Nicolau d'Olwer, L. (1934) «Poesies reialistes del temps de Joan II», Estudis Universitaris Catalans, XIX, pp. 322-334.

Nieto Soria, J. M. (1993) Ceremonias de la realeza. Propaganda y legitimación en la Castilla Trastámara, Madrid, Nerea.

Prince, Dawn E. (2007) «El aragonés literario a finales del siglo XIV. El testimonio del Libro del trasoro», EDACAR (Edizions Dichitals de l'Academia de l'Aragonés), 1 [artículo autorizado y revisado por la autora; traducción y edición a cargo de Francho Rodés; artículo original: (1995) «Literary Aragonese in the Late Fourteenth Century: the Testimony of El Libro del Trasoro", Orbis 38, pp. 80-101].

Riquer, Martí de (1980) Història de la literatura catalana. Part antiga, Barcelona, Ariel, 3 vols. (2 ed.).

Rodrigo Lizondo, M., ed. (2011) Melcior Miralles: Crònica i dietari del capellà d'Alfons el Magnánim, Valencia, Universitat de València.

Rodrigo Lizondo, M., ed. (2013) Col lecció documental de la Cancelleria de la Corona d'Aragó. Textos en llengua catalana (1291-1420). Edició, estudi i índexs a cura de Mateu Rodrigo Lizondo; selecció de textos de Jaume Riera i Sans, València, Universitat de València.

Rubió i Balaguer, Jordi (1984) Història de la literatura catalana, vol. 1, Publicacions de l'Abadia de Montserrat (Biblioteca Abat Oliva, 35).

Rubio Vela, A., ed. (1998) Epistolari de la València medieval (II), València/Barcelona, Institut Interuniversitari de Filologia Valenciana, Publicacions de l'Abadia de Montserrat. 
David Guixeras \& Agustín Rubio Vela. El parlamento de Juan II ante las cortes generales de Monzón (1469). Una pequeña crónica autobiográfica en lengua castellanoaragonesa

Rubio Vela, A. (2012) El patriciat i la nació. Sobre el particularisme dels valencians en els segles XIV i $X V$, Castelló-Barcelona, Fundació Germà Colón Domènech, Publicacions de l'Abadia de Montserrat, 2 vols.

Rubio Vela, A. (2013 [a]) «L'escrivà de ració del príncep de Viana i l'autoria de Tirant lo Blanch. Notes de crítica documental a l'entorn d'un miratge literari», en G. Colón Domènech, ed., Els escriptors valencians del segle XV, Castelló de la Plana, Universitat Jaume I, pp. 109-137.

Rubio Vela, A. (2013 [b]) «El condado de Dénia en tiempos del Tirant. A vueltas con la identidad de Joanot Martorell», eHumanista 23, pp. 557-604.

Rubio Vela, A. (2016) Valencia, el príncipe de Viana y Juan II. Un patriciado ante la crisis política de la monarquia (1460-1461), Valencia, Gráficas Papallona, 2016.

Ryder, Alan (2007) The Wreck of Catalonia: civil war in the fifteenth century, Oxford, Oxford University Press.

Sánchez-Parra, M. P., ed. (1991) Crónica anónima de Enrique IV de Castilla 1454-1474 (Crónica castellana), Madrid, Ediciones de la Torre, 2 vols.

Sans i Travé, J. M., ed. (1992), Dietari o Llibre de Jornades (1411-1484) de Jaume Safont, Barcelona, Fundació Noguera.

Sobrequés i Vidal, S., y Sobrequés i Callicó, J. (1973) La guerra civil catalana del segle XV. Estudis sobre la crisi social i econòmica de la Baixa Edat Mitjana, Barcelona, Edicions 62, 2 vols.

Soldevila, Ferran (1962) Història de Catalunya, Barcelona, Alpha, 2 vols. (2 ed).

Suárez Fernández, L. (2002) Enrique IV de Castilla. La difamación como arma política, Barcelona, Ariel, $3^{\mathrm{a}} \mathrm{ed}$.

Tate, B., y Lawrance, J. (1998-1999) Alfonso de Palencia: Gesta hispaniensia ex annalibus suorum dierum collecta, Madrid, Real Academia de la Historia, 2 vols.

Vicens Vives, J. (1952) Fernando el Católico, príncipe de Aragón, rey de Sicilia, 1458-1478 (Sicilia en la politica de Juan II de Aragón), Madrid, C.S.I.C.

Vicens Vives, J. (2003) Juan II de Aragón (1398-1479): monarquia y revolución en la España del siglo XV, (ed. P. H. Freedman i J. M. Muñoz i Lloret), Pamplona, Urgoiti editores.

Vicens Vives, J. (2006) Historia crítica de la vida y reinado de Fernando II de Aragón, (ed. de M. A. Marín Gelabert), Zaragoza, Institución «Fernando el Católico».

Zurita, Jerónimo (1967-1985) Anales de la Corona de Aragón, (ed. de A. Canellas López), Zaragoza, Institución «Fernando el Católico», C.S.I.C., 9 vols. 


\section{TEXTO}

Comoquiere $^{1}$ que manifestos sean los insultos e danyos del nuestro principado de Catalunya no $\operatorname{ser}^{2}$ a culpa nuestra venidos, por que en darvos razón de aquellos mostremos aquella benignidat e amor a semejantes vassallos devida, e asimesmo por entender con vosotros ensemble en la provisión necessaria e convenible, havemos deliberado convocar las presentes generales cortes. E dezirvos cómo, después de muerto el senyor rey don Alfonso, hermano nuestro, digno de recordación ${ }^{3}$ gloriosa, recebidos nos en la succesión de aquestos senyorios e regnos con la voluntat e obediencia perteneciente e devida, considerados por nos algunos agravios e injusticias resultados de la longua ${ }^{4}$ absencia del dicho ${ }^{5}$ senyor en los senyoríos ${ }^{6}$ de aquá, atendiendo en la reformación de aquellos, convocamos cortes a los aragoneses e catalanes, preparándolas a los valencianos. Las quales cortes continuando, fuemos avisados, por personas a quien ${ }^{7}$ se devia dar fe, que el príncipe don Carlos, fijo nuestro, tractava con algunos adversarios nuestros en Castilla algunas cosas, contrariando al stado nuestro e al pacífico vivir ${ }^{8}$ de vosotros. E por quanto ya en dias passados los dichos adversarios, tractando las semejantes cosas, havían puesto en total ruina ${ }^{9}$ e perdición el regno de Navarra $^{10}$ e havían contra nos, padre, a ell, fijo, puesto en tanta inobediencia que era venido pelear con nos a campal batalla, recelándonos de aquestos regnos la mesma destrucción ${ }^{11}$ que

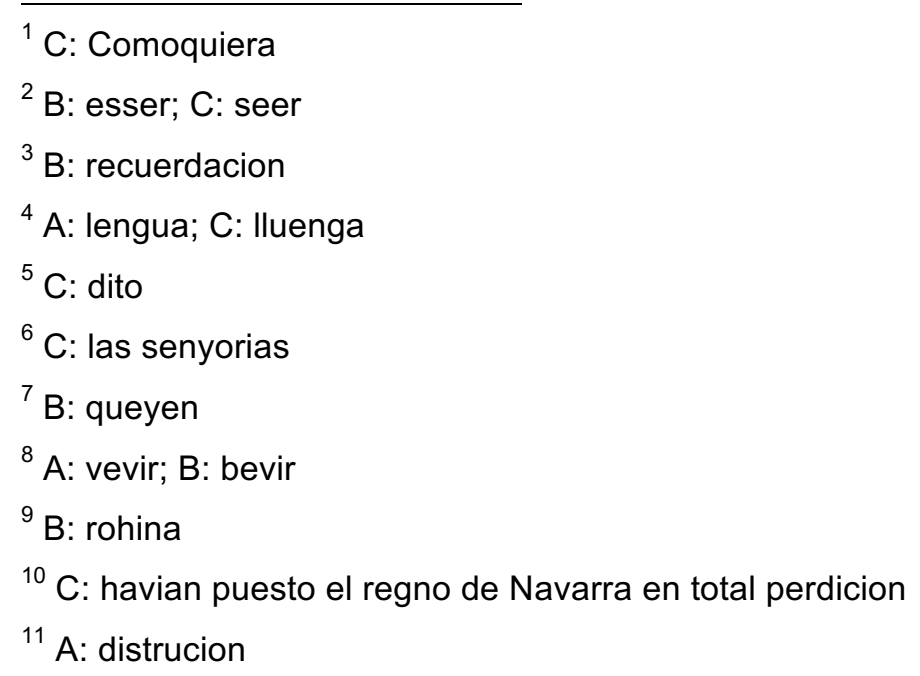

60 
de Navarra, e que, faziendo ${ }^{12}$ a él absentar de nos, tornásemos ${ }^{13}$ a los passados males, deliberamos, con el consejo de algunos principales de nuestros regnos, por evitar los tales inconvenientes, detener la persona del dicho príncipe, a fin que, con la detención de aquell e con la intervención e consejo de los ayuntados en las cortes, pudiésemos ${ }^{14}$ en todo devidamente remediar. ${ }^{15}$

E puestas en aqueste ${ }^{16}$ stado las cosas, algunos de Barcelona, ${ }^{17}$ elevados e ensuperbecidos ${ }^{18}$ por las muchas e excessas ${ }^{19}$ riquezas, assí particulares como generales, haviendo ${ }^{20}$ ya en lo passado, sostraídos entre las necessidades de sus príncipes, tantos e tales privilegios que quasi toda la suprema jurisdicción ${ }^{21}$ de potestat havían ${ }^{22}$ a sí transferida, se desdenyavan ya de tener superior ninguno; e, puesto que lo tuviesen, quisieran que fuese solamente de nombre. Los quales, la hora que vieron por la detención de nuestro fijo algún tanto comovidos $^{23}$ los pueblos, entendieron luego ${ }^{24}$ en excitar hi albolotar ${ }^{25}$ aquellos a fin que de aquesto resultasen algunas novidades, mediante ${ }^{26}$ las quales, diminuyendo ${ }^{27}$ la nuestra, pudiessen ${ }^{28}$ augmentar la potestat suya. E de

\footnotetext{
${ }^{12} \mathrm{~B}$ : fazendo

${ }^{13} \mathrm{C}$ : tornassamos

${ }^{14} \mathrm{~B}, \mathrm{C}$ : podessemos

${ }^{15} \mathrm{~B}$ : remadiar

${ }^{16} \mathrm{~B}, \mathrm{C}$ : aquest

${ }^{17} \mathrm{~A}, \mathrm{C}$ : Barchinona

${ }^{18} \mathrm{~B}$ : ensuperbidos

${ }^{19} \mathrm{C}$ : extremas

${ }^{20} \mathrm{~B}$ : haveyendo

${ }^{21}$ B: jurediccion; C: juridiccio

${ }^{22} \mathrm{~B}$ : havien

${ }^{23}$ A: movidos

${ }^{24}$ B: loego

${ }^{25}$ B: alvalotar; C: avolatar

${ }^{26} \mathrm{~A}$ : mediantes

${ }^{27} \mathrm{~B}, \mathrm{C}$ : diminuendo

${ }^{28} \mathrm{~B}$ : podiessen
} 
fecho, ${ }^{29}$ en virtut de General, se formó un consejo de vintisiete ${ }^{30}$ personas dentro la ciudat de Barcelona ${ }^{31}$ regido e agabellado por los sobredichos comovedores, la potestat del qual amplificaron tanto que en respecto de aquella restava la nuestra ${ }^{32}$ quasi ninguna.

E de aqueste consejo partió ${ }^{33}$ una enbaxada a nos sobre la detención del príncipe, por medio de la qual nos fueron explicadas palabras ${ }^{34}$ e razones tales que eran más dispuestas provocarnos a indignación que a benignidat, según ${ }^{35}$ el intento de aquellos por quien eran enviados. Con todo, empero, justificando las causas de la dicha detención, dimos de nos aquella razón que al caso convenia. E por más a comodament poder las cosas negociar, venimos, e los embaxadores con nos, a Lérida, ${ }^{36}$ e aquí disposimos e dimos orden a las cosas por ellos suplicadas. Sobre lo qual consultados, $\operatorname{los}^{37}$ principales, que discordia deseavan, so $^{38}$ color de fazer repuesta, multiplicaron en nombre de sexanta ${ }^{39}$ los primeros embaxadores a fin que, más refforçados ${ }^{40}$ en una, pudiesen ${ }^{41} \mathrm{e}$ ossasen executar mejor sus pravos e malvados conceptos, siempre que requeridos fuesen. Los quales querer ${ }^{42}$ contractar humilmente con nos

\footnotetext{
${ }^{29}$ B: feyo

${ }^{30} \mathrm{~B}$ : vint e seyte; C: vint y sete

${ }^{31}$ A, C: Barchinona

${ }^{32} \mathrm{C}$ : nuestra casa

${ }^{33} \mathrm{C}$ : preceyo

${ }^{34} \mathrm{C}$ : parauablas

${ }^{35} \mathrm{C}$ : segund

${ }^{36}$ B: a la Lleyda

${ }^{37} \mathrm{~A}, \mathrm{~B}$ : que

${ }^{38} \mathrm{~B}, \mathrm{C}$ : sots

${ }^{39}$ A: sixanta

${ }^{40}$ A: forçados; B: sforçados

${ }^{41} \mathrm{~B}$ : podiessen

42 B: quyerar
} 
significaron, e de fecho contractamos ${ }^{43}$ e fuemos de acuerdo, según e por ${ }^{44}$ la forma por ellos mesmos instada e suplicada.

$\mathrm{E}$ en aquesto stando, ${ }^{45}$ fuemos súbitamente avisados que algunos malvados de los embaxadores, armados, ensenble con el pueblo de la ciudat, venían la vía de nuestro palacio a fin de poner las manos e ${ }^{46}$ nos e matar todos los principales de nuestra casa que allí se fallavan; ${ }^{47}$ por la qual cosa convinió ${ }^{48}$ a nos hir $^{49}$ scondidamente ${ }^{50}$ la vía de Fraga, restando tanto turbados e maravillados ${ }^{51}$ de $\tan ^{52}$ feo e detestable insulto, que, puesto lo viéssemos, ${ }^{53}$ no 60 se nos lexava ${ }^{54}$ creer. $\mathrm{Hi}^{55}$ más ahún, por provar si en aquesto algún remedio fallarse pudiera, ${ }^{56}$ enviamos a la infanta dona Beatriz, nuestra hermana, a Lérida, e a Barcelona ${ }^{57}$ el maestre ${ }^{58}$ de Muntesa e el virei ${ }^{59}$ de Sicilia, ${ }^{60}$ don Lop Ximénez ${ }^{61}$ d'Urrea, proferiendo ${ }^{62}$ de nuestras partes todas e qualesquiere ${ }^{63}$

\footnotetext{
${ }^{43} \mathrm{C}$ : con ora certamos

${ }^{44} \mathrm{C}$ : segunt por

${ }^{45} \mathrm{~A}$ : aquesto stado; C: aquest stado

${ }^{46} \mathrm{C}$ : an

${ }^{47} \mathrm{C}$ : fallarian

${ }^{48} \mathrm{~B}, \mathrm{C}$ : convenió

${ }^{49} \mathrm{C}$ : foyr

${ }^{50} \mathrm{~B}$ : ascondidamente

${ }^{51} \mathrm{~B}$ : maravellados

${ }^{52} \mathrm{C}$ : tant

${ }^{53}$ B: vessemos; C: veessemos

${ }^{54}$ C: lexaria

55 'Hi', omitido en B; C: et

${ }^{56}$ B, C: podiera

${ }^{57}$ A, C: Barchinona

${ }^{58} \mathrm{~B}$ : mestre

${ }^{59}$ A: bisrei; C: visrey

${ }^{60}$ B: Secilia

${ }^{61}$ C: Eximez

${ }^{62}$ B: profieriendo; C: profferiendo

${ }^{63} \mathrm{~B}$ : qualsqyere; C: qualesquiera
} 
cosas que, assí a la detención del príncipe como a todos los otros inconvenientes, satisfazer pudiessen. ${ }^{64}$

Los caborales, pero, ${ }^{65}$ del dicho consejo, deseando siempre, no concordia, mas rompimiento, ${ }^{66}$ en lugar de respuesta, gente armada a cavallo e a pie contra nos embiaron. Nos, empero, por no dar lugar a sus ${ }^{67}$ perversos e infides $^{68}$ acometimientos, a Çaragoça volvimos ${ }^{69}$ e, reconocidas ${ }^{70}$ las cosas contra el príncipe opuestas, ${ }^{71}$ por sernos fijo, ser de clemencia dignas ${ }^{72}$, liberamos $^{73}$ aquel. E por provar si con benignidat e complazimientos podríamos ${ }^{74}$ reconciliar a nos los ánimos ${ }^{75}$ de los sobredichos caborales, ${ }^{76}$ enviamos el dicho nuestro fijo a ellos, e la reyna, nuestra mujer, con él.

Aquellos, empero, que puesto fingiesen ${ }^{77}$ que sí, deseavan muy poco la 75 liberación ${ }^{78}$ del dicho príncipe, visto que so ${ }^{79}$ aquella color tenían hi ${ }^{80}$ el consejo e las armas en manos suyas, veyendo que las cosas fechas por nos no conferían punto con la intención suya, mudaron consejo e, abscondidamente del príncipe,

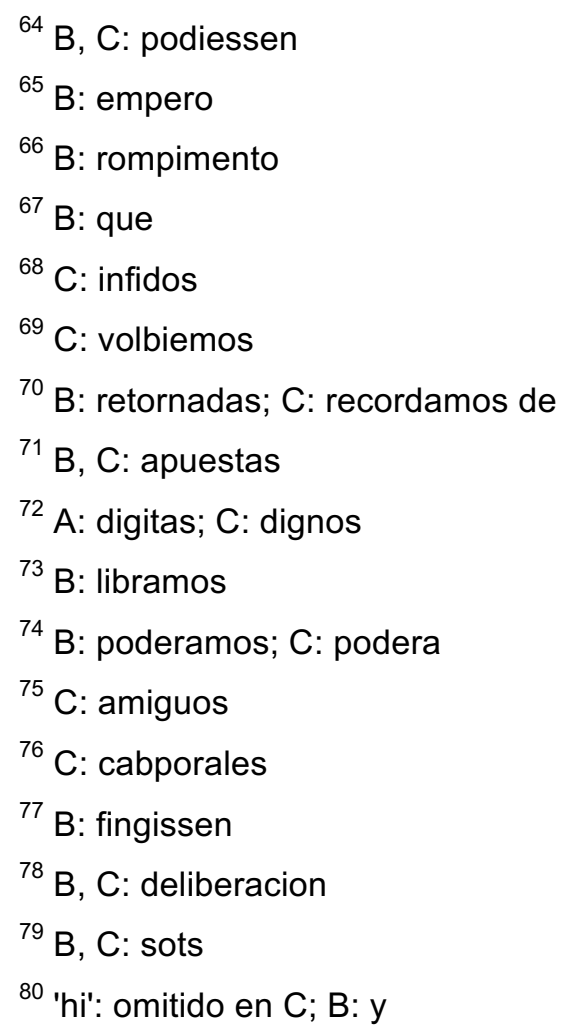


entraron $^{81}$ en nuevas contractaciones con la reyna, forjando una cierta capitulación tal que no quedava más senyoría en Catalunya a nos que quanto a ellos pluguiese ${ }^{82}$ e que el príncipe no haviese ${ }^{83}$ en ellos sino el nombre solo de senyor. La perversidat ${ }^{84}$ de la qual capitulación, ahunque por nos bien conocida ${ }^{85}$ fuese, por esquivar mayores inconvenientes, ${ }^{86}$ veyéndolos $^{87}$ dispuestos $^{88}$ a qualesquiere $^{89}$ maldades, deliberamos firmar. $E$ assí alcançado por ellos el fin deseado de poder absolutamente ${ }^{90}$ regir, retenido el príncipe consigo, de poca e 85 quasi ninguna jurisdicción ${ }^{91}$ dexándole usar, aquesto molestamente ${ }^{92}$ sofriendo, ${ }^{93}$ cayendo $^{94}$ en mortal dolencia, feneció ${ }^{95}$ sus días.

Después la muerte del qual, haviendo provado los sobredichos quánto plaziente cosa era, so ${ }^{96}$ velo de senyor, retener ${ }^{97}$ ellos $^{98}$ la senyoría consigo, veyendo el príncipe don Ferrando, fijo nuestro, en edat ${ }^{99}$ de onze anyos, edat dispuesta para ${ }^{100}$ poder ellos mejor a la voluntat suya regir, enviaron por él,

\footnotetext{
${ }^{81} \mathrm{~A}$ : entard

${ }^{82} \mathrm{C}$ : pluviesse

${ }^{83} \mathrm{C}$ : viniesse (?)

${ }^{84} \mathrm{C}$ : penositat

${ }^{85} \mathrm{~B}, \mathrm{C}$ : conoscida

${ }^{86} \mathrm{~B}$ : enconvenientes

${ }^{87} \mathrm{C}$ : veyendoles

${ }^{88} \mathrm{~B}$ : dispostos

${ }^{89} \mathrm{C}$ : qualesquiera

${ }^{90} \mathrm{~A}$ : absolutament

${ }^{91}$ A: jurediccion; $C$ : jurigdiccio

${ }^{92} \mathrm{C}$ : molestament

${ }^{93} \mathrm{~B}$ : soffreyendo; C: soffrendo

${ }^{94} \mathrm{C}$ : quexando

${ }^{95} \mathrm{C}$ : finio

${ }^{96} \mathrm{C}$ : sots

${ }^{97} \mathrm{C}$ : detener

98 'ellos': omitido en C

99 'en edat': omitido en $\mathrm{C}$

100 A: pora
} 
segunt que ya ${ }^{101}$ en la dicha ${ }^{102}$ capitulación havían provehido. El qual, venido en Barchinona con la reyna, su madre, fecha por ella alguna contradicción en su absoluto govierno, ${ }^{103}$ començaron a preparar ${ }^{104}$ e mover nuevos scándalos. Aconteció, pero, ${ }^{105}$ en este ${ }^{106}$ medio tiempo, levantarse algunos pageses de remença, en las partes de Ampurdán, ${ }^{107}$ contra los senyores suyos; e consejando, instando ${ }^{108}$ e requiryendo ${ }^{109}$ los dichos caborales, la reyna, ensemble con el príncipe, fizieron ${ }^{110}$ la via de Gerona por castigar e punir ${ }^{111}$ los tales insultos. E aquesto fue instado ${ }^{112}$ e consejado, ${ }^{113}$ segunt ${ }^{114}$ pareció ${ }^{115}$ después, que, aquellos fuera de la ciudat, pudiessen ${ }^{116}$ mejor conduzir sus iniquos e malos conceptos al fin deseado. E lleguados la reyna e príncipe a la ciudat de Gerona ${ }^{117}$ procediendo ${ }^{118}$ contra los dichos pageses, fizo enforcar dos d'ellos, qui se fallavan culpables.

\footnotetext{
${ }^{101} \mathrm{C}$ : segund ya

102 B: dita

${ }^{103}$ B: governo

${ }^{104} \mathrm{C}$ : praparar

${ }^{105} \mathrm{~B}$ : enpero

${ }^{106}$ B: sto; C: est

${ }^{107} \mathrm{C}:$ Ampurda

${ }^{108} \mathrm{C}$ : stando

${ }^{109} \mathrm{~B}, \mathrm{C}$ : requirendo

${ }^{110} \mathrm{C}$ : fueron

${ }^{111} \mathrm{~B}$ : opremir

${ }^{112} \mathrm{C}$ : stado

${ }^{113} \mathrm{C}$ : aconsejado

${ }^{114} \mathrm{C}$ : segund

${ }^{115}$ B: paresció

${ }^{116} \mathrm{~B}$ : podiessen

${ }^{117}$ A: Girona

${ }^{118} \mathrm{~A}$ : procidiendo
} 
E tomando escusa los sobredichos ${ }^{119}$ caborales que no se $^{120}$ fazía la justicia assí rigorosa como se devía, soldearon gente de armas, de pie e de cavallo, capitán d'ellos el conde de Pallás, e, so ${ }^{121}$ color de castigar los pageses, ${ }^{122}$ embiaron aquell la vía de Gerona. Dentro la qual ciudat, teniendo ${ }^{123}$ concierto con algunos, les fueron ${ }^{124}$ abiertas las puertas, ${ }^{125}$ e, con las armas furiosamente entrando, falleció ${ }^{126}$ muy poco de tomar la reyna e príncipe, stando descuydados de sus iniquos intentos. Los quales, recogidos dentro la fuerça vieja 110 de la dicha ${ }^{127}$ ciudat, fueron luego por los dichos ${ }^{128}$ adversarios sitiados. E tirando ${ }^{129}$ con lombardas ${ }^{130}$ e mucha otra artellería, ${ }^{131}$ dando muy fuertes e continuos combates, trabajavan ${ }^{132}$ con suma diligencia de tomar aquella, ${ }^{133}$ usando de tanta inhumanidat e crueza que fazían muy a menudo tirar la dicha artellería $^{134}$ a la posada donde ${ }^{135}$ sabían que los senyores suyos stavan, sin que jamás ${ }^{136}$ vianda alguna, fasta una poca de fruita, al tierno ninyo consentieron que fuese dada. E maravillándose ${ }^{137}$ la reyna de casos tanto detestables, les envió

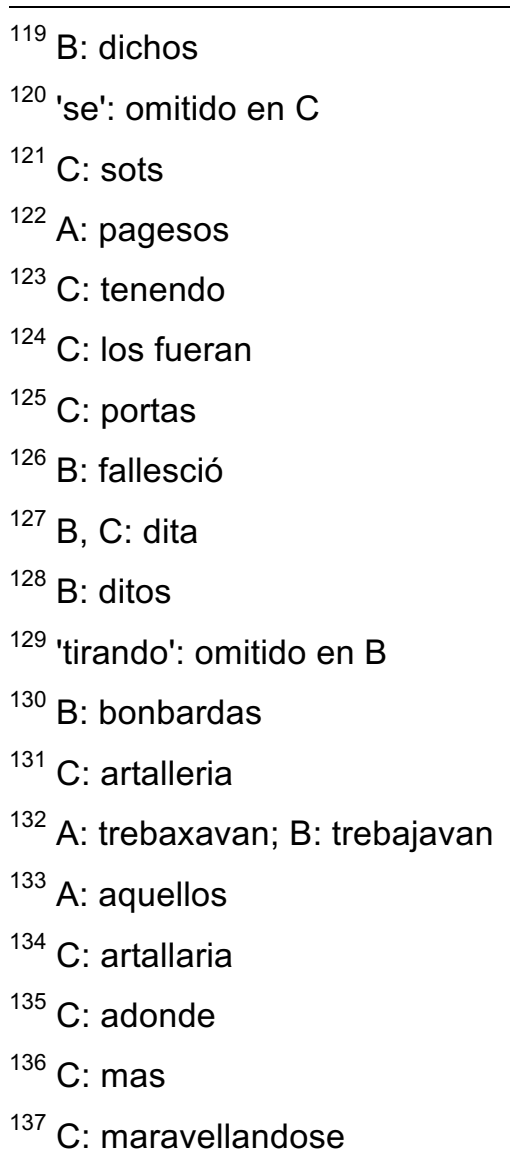


dezir $^{138}$ con mosén Cartellán ${ }^{139}$ les rogava ${ }^{140}$ dexassen yr a ella, a su fijo e a todos los otros, e que $\operatorname{los}^{141}$ lexaría ${ }^{142}$ líberamente la fuerça; e, si no, dixesen qué demandavan. La respuesta fue que como fuesen entrados le ${ }^{143}$ respondrían; e sabemos havían deliberado que, entrada la fuerça, fuessen puestos $a^{144}$ la spada, ensemble ${ }^{145}$ con todos los otros, nuestra ${ }^{146}$ muger e fijo.

Aquestas cosas todas notificadas a nos en Çaragoça, restamos no poco congoxados por ver ${ }^{147}$ en tanta presura ${ }^{148}$ las personas a nos tanto caras; con todo, pero, ${ }^{149}$ quisimos ${ }^{150}$ provar si pacíficamente se podiera remediar, e de 125 fecho dimos orden que los enbaxadores del rey don Ferrando, sobrino nuestro, e ahún otros de nuestro reyno de Valencia, fuessen a Barchinona e dixesen a los del consejo les pluguiese ${ }^{151}$ lexar ${ }^{152} \mathrm{yr}$ del sitio a nuestra mujer e fijo, e a los que ${ }^{153}$ con ellos eran, offreciendo de nuestras partes que, si algunos ${ }^{154}$ agravios o sinrazones pretendiesen, ${ }^{155}$ o gracias algunas demandasen, serían reparados

\footnotetext{
${ }^{138} \mathrm{C}$ : a dezir

${ }^{139}$ C: Cartella

${ }^{140} \mathrm{~B}$ : les rogavan les; C: le rogava le

${ }^{141} \mathrm{~A}$ : les

142 B: dexaria

${ }^{143} \mathrm{~A}, \mathrm{~B}$ : les

${ }^{144} \mathrm{~B}$ : en

145 B: consenble

${ }^{146} \mathrm{~B}$ : con nuestra

${ }^{147} \mathrm{~B}$ : veher

${ }^{148} \mathrm{~B}$ : appressura

${ }^{149} \mathrm{C}$ : empero

150 B: quisiemos; C: quesimos

${ }^{151} \mathrm{~B}$ : pluuisse; C: plasiesse

152 B: dexar

${ }^{153}$ A, B: e los qui

${ }^{154} \mathrm{C}$ : negunos

${ }^{155} \mathrm{C}$ : pretendessen
} 
e satisfechos ${ }^{156}$ segunt e por ${ }^{157}$ la forma que los dichos embaxadores apuntarían con ellos; e, donde no, declarasen qual era la intención suya. Mas ellos, assí los embaxadores como los ofrecimientos desdenyando, significaron asaz claramente $^{158}$ ninguna otra cosa plazerles ${ }^{159}$ sino la senyoria. E veyendo ${ }^{160}$ nos que drecho, razón ${ }^{161}$ e ahún lealtat eran totalmente apartados de los ánimos suyos, hi que el remedio restava solamente en las armas, nos disposimos ${ }^{162}$ a ellas. E sentiendo ${ }^{163}$ que $\cdot I^{164}$ rey de Castilla se preparava ayudar contra nos a los rebelles, concordamos con el rey de Francia que, valiéndonos con seyscintas ${ }^{165}$ lanças fasta haver reduzido ${ }^{166}$ a obediencia ${ }^{167}$ nuestros vassallos, le dávamos doszientos mil ${ }^{168}$ scudos, $\mathrm{y}^{169}$ en tanto que no se pagarían, 140 tuviese ${ }^{170}$ en poder las rentas de Rosellón. Los quales pactos con ${ }^{171}$ juramento rompiendo, después se ha usurpado injustamente e sin nuestro consentimiento $^{172}$ el condado de Rossellón e de Cerdanya. E viniendo ${ }^{173}$ nos a Balaguer a fin de socorrer nuestra mujer e fijo e a tantos buenos con ellos

\footnotetext{
${ }^{156} \mathrm{C}$ : reparadas e satisfechas

${ }^{157} \mathrm{C}$ : segund por

${ }^{158} \mathrm{~B}$ : claramiente

${ }^{159}$ C: placerlos

${ }^{160} \mathrm{C}$ : veendo

161 'razón': omitido en B

${ }^{162} \mathrm{C}$ : desposimos

${ }^{163} \mathrm{~B}$ : Et, sentindo

${ }^{164} \mathrm{C}$ : que

${ }^{165}$ A: DC; C: siscentas

${ }^{166} \mathrm{C}$ : reduzidos

167 'obediencia': omitido en $C$

${ }^{168} \mathrm{~A}$ : $\mathrm{CC}^{\mathrm{os}} \mathrm{mil}$; B: $\mathrm{CC}^{\mathrm{m}}$

169 ' $y$ ' se omite en C; B: hi

${ }^{170} \mathrm{~A}$ : tomasse; B: toviessen

${ }^{171} \mathrm{C}$ : de

${ }^{172} \mathrm{C}$ : consintimiento

${ }^{173} \mathrm{~A}$, B: veniendo
} 
encerrados, socorridos en este medio por la gente francesa, fueron liberados de sus crueles manos.

En tanto, pero, que las sobredichas ${ }^{174}$ cosas passavan, veyendo los caporales del consejo que la maldat suya era del todo descubierta, ${ }^{175}$ servando infinitas $^{176}$ cautelas, stucias e falsedades, tomada secreta intelligencia con los regidores de las ciudades ${ }^{177}$ e villas, pusieron ${ }^{178}$ la mayor parte de Catalunya en manifiesta ${ }^{179}$ rebellión. $E$ finalmente, tomando forma de común regimiento, tanto por ellos deseado, principiaron cosa enorma, detestable e inaudita: que ellos, vasallos, publicaron e pregonaron ${ }^{180}$ a nos, su natural senyor, por capital enemigo.

$\mathrm{E}$ tomadas las armas abiertamente ${ }^{181}$ contra nos, fueron mediante la divina $^{182}$ justicia siempre vencidos, en tal manera que, fallándose perdidos del todo, e fustrados de sus superbas ${ }^{183}$ e vanas presumpciones, invocaron por adiutor e senyor el rey de Castilla. E después que fueron por él desechados, embiaron para ${ }^{184}$ se dar al rey de Francia, la qual cosa, sentida por los menudos pueblos aborresciendo ${ }^{185}$ la senyoria francessa, intitularon rey de Aragón a don Pedro de Portugal. ${ }^{186}$ Después la ${ }^{187}$ muerte del qual, nuestro santo padre Paulo,

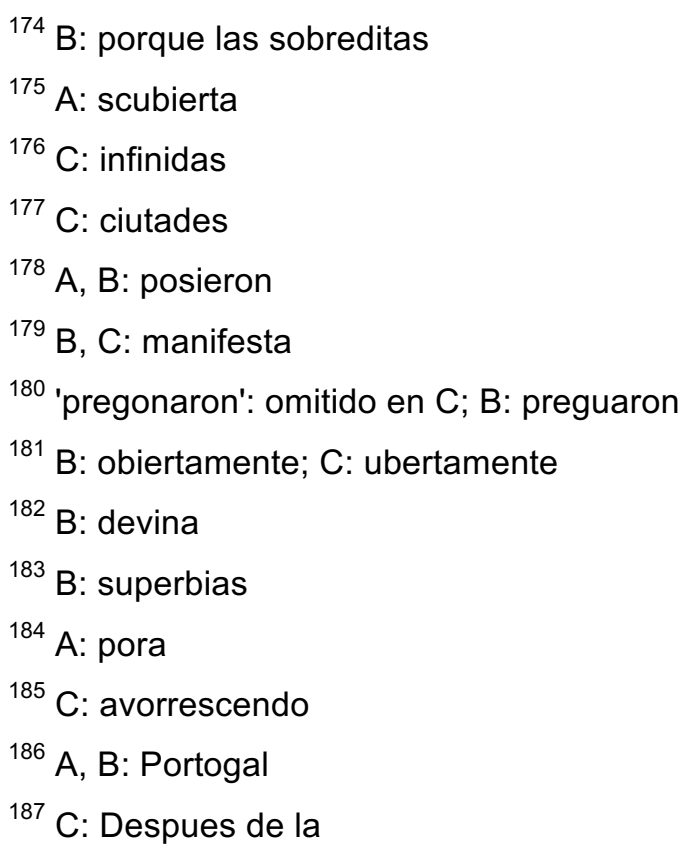


quisiendo se interposar a pacifficación ${ }^{188}$ d'ellos con nos, les envió nuncio proprio, con breve suyo bullado, exortándolos ${ }^{189}$ a concordia con nos, su rey e senyor; e ellos, menospreciando tan santa ${ }^{190}$ e honesta amonestación, ${ }^{191}$ no solamente lo recusaron fazer, mas ahún, endurecidos en su pertinacia, proclamaron de nuevo por rey e senyor el duque Reyner. ${ }^{192}$

En todo aqueste discurso ${ }^{193}$ de tiempo han seýdo por nos muchas vezes rogados, exortados e requeridos, assí por religiosas personas como por muchas ${ }^{194}$ otras, quisiesen dar lugar a pacificación ${ }^{195}$ e concordia, mas, nin por haver mostrado tanta pasciencia en sus ${ }^{196}$ malvados insultos, nin por haver ${ }^{197}$ usado de mucha clemencia en los vencimientos, nin por haverles fecho ${ }^{198}$ grandes e pacífficos ${ }^{199}$ ofrecimientos, nin por otras infinitas ${ }^{200}$ vías amonestados, havemos podido ${ }^{201}$ mitigar jamás ${ }^{202}$ la malignidat suya; antes ha convenido a nos, como forçado, guerrear $\operatorname{con}^{203}$ nuestros mesmos vassallos e destruir ${ }^{204} \mathrm{e}$ gastar nuestros propios ${ }^{205}$ bienes. E, ultra de aquesto, nos ha convenido, a fin

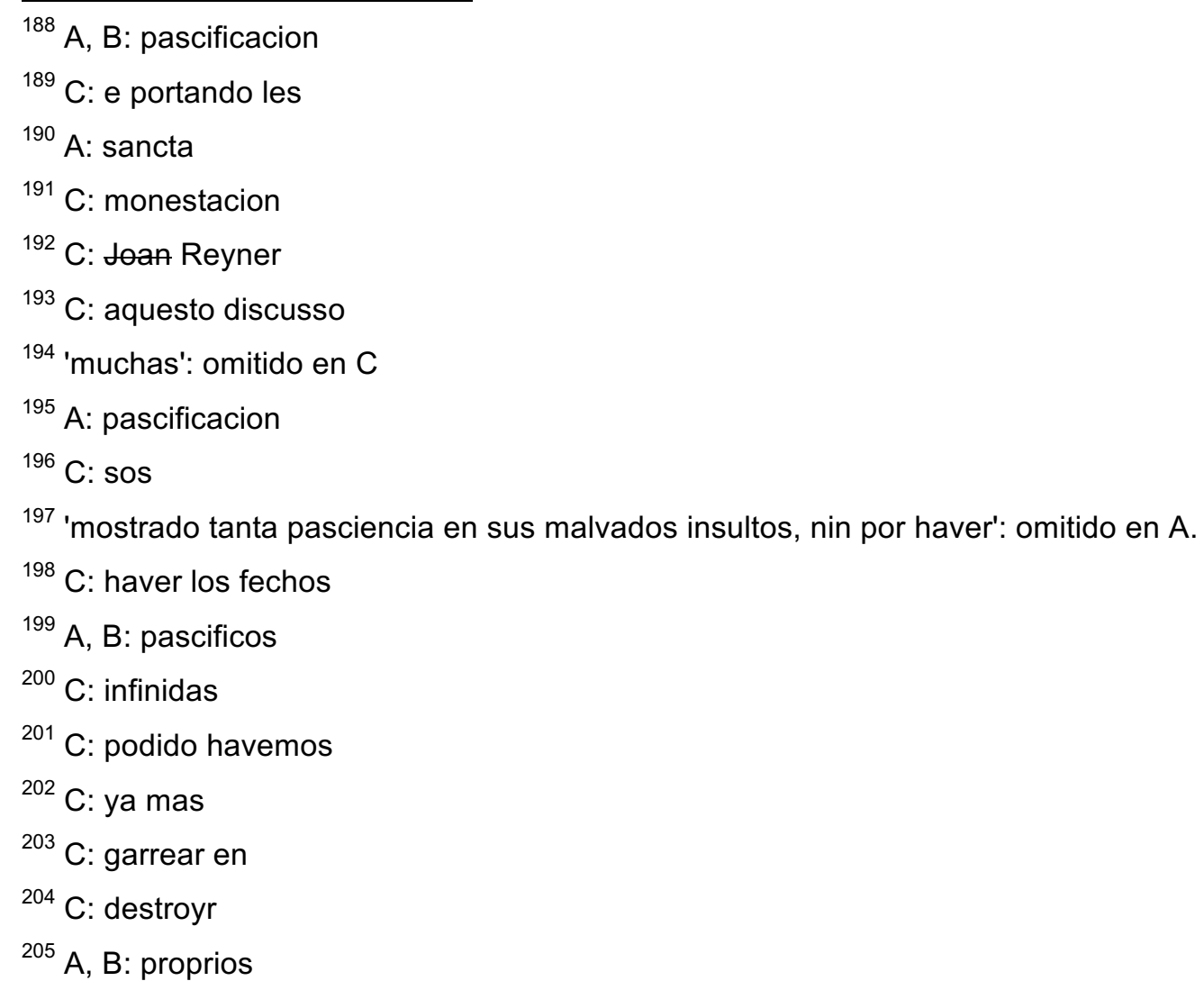


175 de alcançar ${ }^{206}$ paç, proseguir en tal manera la guerra que, dexando aparte toda natura de plazeres, sin perdonar a nuestra edat nin guardar a la real preheminencia, ${ }^{207}$ havemos ofrecido ${ }^{208}$ la persona a qualesquiere ${ }^{209}$ trabajos, $^{210}$ periglos e infortunios, ${ }^{211}$ sin que en verdat no havemos perdonado a los bienes; antes, havemos tantos gastados e consumidos en la presente guerra que passan sin dubdo ${ }^{212}$ muchos millares de florines.

En todas estas cosas, pero, ahunque diversamente, havemos seýdo de vossotros siempre aconpanyado. ${ }^{213}$ Car los aragoneses nos ${ }^{214}$ havéys servido en general con tantas ${ }^{215}$ gentes e tales, que han principalmente defendido el estado nuestro; e en singular havéys assí virtuosamente obrado en esta guerra, poniendo con entera afección las personas e bienes, que quedáys por exemplo de lealdat entre todas las naciones. Los valencianos por cierto havéys usado de tanta virtud en aquestos tiempos que jamás ${ }^{216}$ se ha mostrado $\mathrm{ni}^{217}$ preparado offensión ninguna dentro del reyno ${ }^{218}$ que por vosotros no haya seýdo animosamente opugnada e expellida; e havemos seýdo assí bien servido de muchos, ${ }^{219}$ en singular e universal, que no solamente nos, mas los descendientes $^{220}$ nuestros quedan en obligación de vosotros. De los

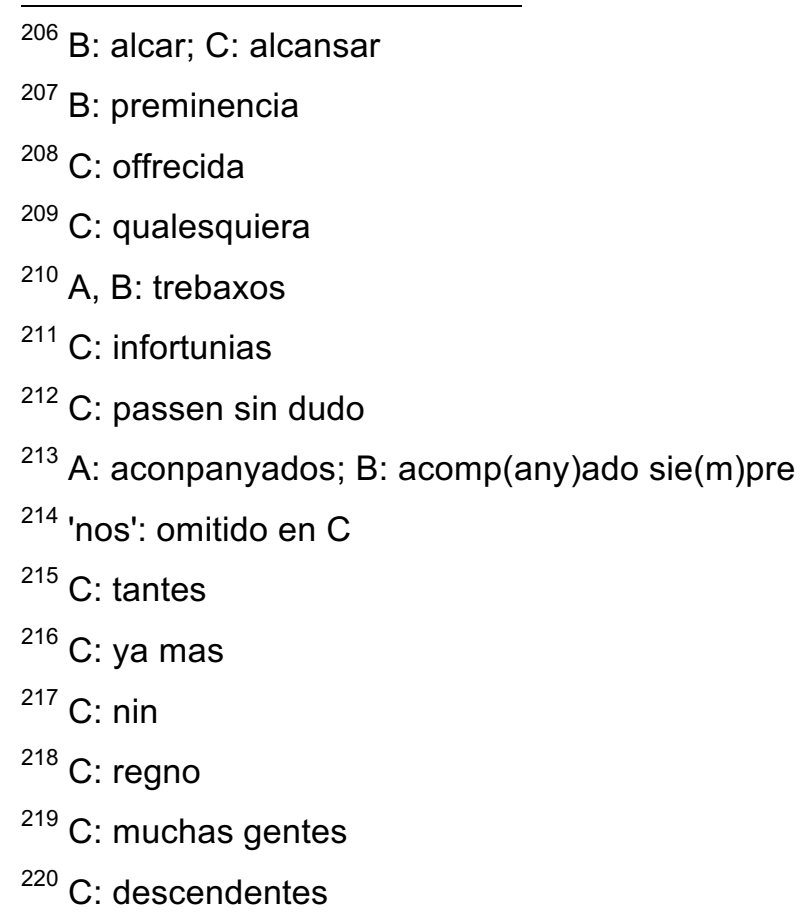


mallorquines havemos recebido por la mar tales e tantas valenças ${ }^{221}$ que han mostrado no $^{222}$ passarles en voluntat ningunos de los otros vasallos. Qué diremos de los cathalanes, sino que, por cierto no haver ${ }^{223}$ seýdo tanta la infidelidat e maldat de los rebelles, que la sinceritat e bondat de vosotros, leales $\mathrm{e}^{224}$ fieles, no haya seýdo mayor; car no solamente havéys derramado la sangre e ofrecido las vidas muchas vezes por la defensión del stado nuestro, mas, posposando a la honor todas las otras cosas, havéys desemparado vuestras casas, perdido ${ }^{225}$ vuestros patrimonios e abandonado ${ }^{226}$ vuestros parientes, mujeres e fijos, e nos havéys ayudado quanto havéys podido de vuestros proprios bienes. E, finalmente, podemos con verdat dezir que no fue ni ha podido ser jamás ${ }^{227}$ en el mundo senyor ${ }^{228}$ mejor $^{229}$ de subjectos ${ }^{230}$ servido.

Nos havemos a vossotros fallado ${ }^{231}$ en fidelidat vassallos, en las subvenciones amigos e en obediencia fijos. Con vosotros ensemble havemos ganado ${ }^{232}$ Lérida, tomado Cervera, cobrado Tortosa e, finalmente, gran ${ }^{233}$ part de Cathalunya. Como, empero, el devido lahor de las cosas consista en el fin de aquellas, visto que los principios e medios ${ }^{234}$ han seýdo tanto ${ }^{235}$ loables,

\footnotetext{
${ }^{221}$ A: velenças; C: valences

${ }^{222} \mathrm{C}$ : non

${ }^{223} \mathrm{C}:$ ha

224 'Ieales e': omitido en C

${ }^{225}$ B, C: perdidos

${ }^{226}$ A, B: bandonado

${ }^{227} \mathrm{C}$ : esser ya mas

${ }^{228}$ B: senyor en el mundo

${ }^{229}$ C: mayor

${ }^{230} \mathrm{C}$ : subjecto

${ }^{231} \mathrm{C}$ : fallado a vossotros fallado

${ }^{232} \mathrm{C}$ : ganada

${ }^{233}$ A, B: grant

${ }^{234}$ C: medio

235 'tanto': omitido en B.
} 
trabajemos $^{236}$ e entendamos conduzirlos al devido fin, el qual devemos sin ninguna duda ${ }^{237}$ sperar si consideramos de quánta justicia es acompanyado.

¿Quáles armas fueron jamás más justamente tomadas que contra vassallos entendiendo e pugnando continuamente quitar el stado e vida a su natural senyor sin que de tiranía de justicia ni de crueldat — ¡Dios loado ${ }^{238}$ ! — puedan dar ninguna razonable querella? La superbia suya ha seýdo tanto extrema que no solamente $\operatorname{los}^{239}$ ha trahído a tan iniqua rebellión contra nos, mas ahún haver ${ }^{240}$ 215 presumido de haver, ${ }^{241}$ quitar e poner rey al ${ }^{242}$ arbitrio suyo a reynos ${ }^{243}$ tanto insignes, e dar senyor a personas tanto preheminentes, ${ }^{244}$ que muchos de vosotros tenéys mejores ${ }^{245}$ servidores que ellos no son. E no cessando ahún, trabayan $^{246}$ continuamente que vosotros, de tantas gentes conquistadores, hayáys de ser conquistados a mano suya de franceses, antigos enemigos vuestros, la dura e superba ${ }^{247}$ senyoría de los quales pudo jamás ${ }^{248}$ ninguna nación soportar. ${ }^{249}$ ¡Quánto más vosotros, de quien recuerdan los tantos vencimientos, las tantas ofensas con tantos derramamientos ${ }^{250}$ de sangre fechos en ellos por vuestros antecessores! La vengança de las ${ }^{251}$ quales cosas

\footnotetext{
${ }^{236} \mathrm{~A}$, B: trebajemos

${ }^{237}$ A, B: dubda

${ }^{238}$ B: loable

${ }^{239}$ A, B: les

${ }^{240} \mathrm{C}$ : han

241 'haver': omitido en B.

${ }^{242}$ B: a

${ }^{243} \mathrm{C}$ : regnos

${ }^{244}$ A, B: preminentes

${ }^{245} \mathrm{C}$ : meyores

${ }^{246} \mathrm{~A}, \mathrm{~B}$ : trebaxan

${ }^{247}$ C: superbia

${ }^{248} \mathrm{C}$ : ya mas

${ }^{249}$ A, B: suportar

${ }^{250} \mathrm{C}$ : derramimentos

${ }^{251} \mathrm{C}$ : los
} 
prosiguiendo, ${ }^{252}$ son ya con las armas en las manos, ${ }^{253}$ no solamente dentro la patria, mas asaz vezinos de aquí.

Por tanto, vos rogamos, encargamos e exortamos, como a fieles e buenos vassallos, ${ }^{254}$ que, pues tenemos ${ }^{255}$ causas no solo justas, mas necessarias, de guerrear $^{256}$ por aconseguir paç e reduzir los que andan assí errados a vera obediencia de nos, su rey e senyor natural, se entienda, con aquella diligencia ${ }^{257}$ e promptitut que el caso requiere, ${ }^{258}$ dar expedición a las cosas a los fines sobredichos necessarias et oportunas. E quanto a la gente, scusado buscar, ${ }^{259}$ car por cierto entre todas las naciones del mundo soys vosotros en el exercicio de las armas singularmente dispuestos; ${ }^{260}$ assimismo ${ }^{261}$ havemos vituallas asaz; aquello que principalmente fallece son pecunias; e dar orden a la distribución de aquellas, faziendo, entre las otras provisiones, algún número de gente e sfuerço por mar e por tierra, la qual sea continuamente pagada fasta sean expellidos los enemigos e tornados a la devida obediencia los vassallos que ${ }^{262}$ han querido e quieren con protervidad deviar de la casa d'Aragón.

Las quales cosas son muy fáciles si drechamente e concordable seran proseguidas, ${ }^{263}$ e otramente quasi inposible es, ${ }^{264}$ car la recta intención en las

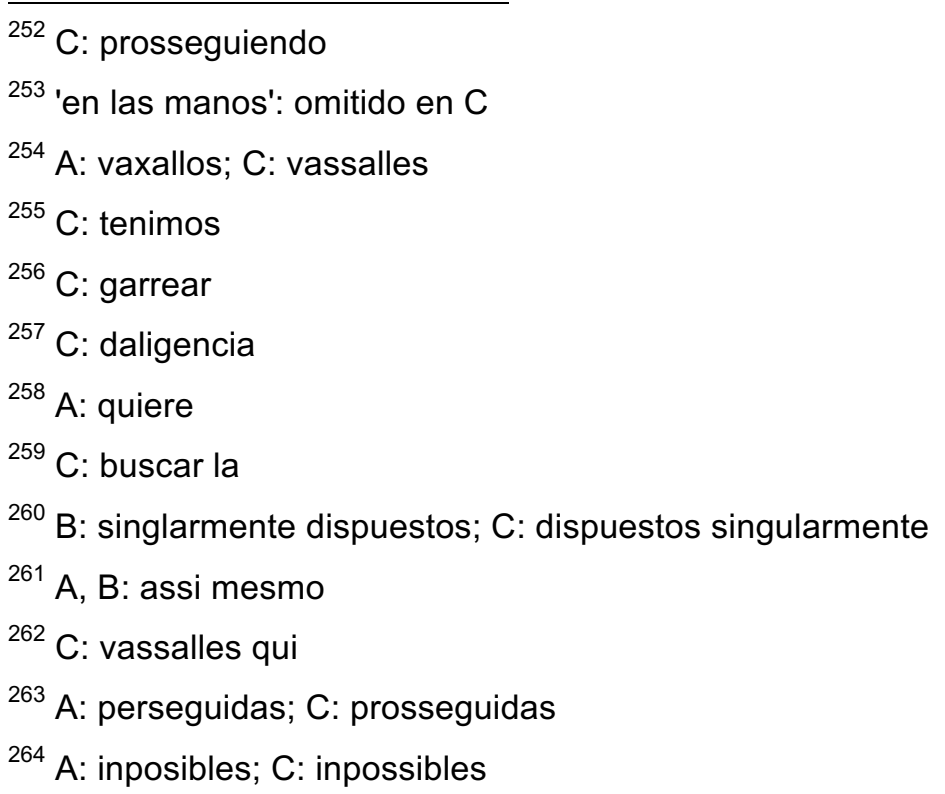


voluntades conformes ${ }^{265}$ faze $^{266}$ de las cosas pequenyas grandes e trahe $e^{267}$ a prosperado fin los difíciles principios. ${ }^{268}$ De quanto tocará al trabajo ${ }^{269}$ de la persona nuestra e a la disposición de nuestros emolumentos e rentas, ${ }^{270}$ dexamos $^{271}$ al arbitrio de vosotros, en manos ${ }^{272}$ e poder de los quales, encomendando el stado ${ }^{273}$ nuestro, vos recordamos ${ }^{274}$ que, entre ${ }^{275}$ vuestras deliberaciones, queráys considerar aquello que al honor e virtud ${ }^{276}$ vuestra conviene, e guardar ${ }^{277}$ aquello que a la nuestra real dignidat es perteneciente $e^{278}$ e devido, siempre sobre todas cosas confiando en la infinida bondat de nuestro senyor Dios, que, mediante ${ }^{279}$ la intercessión de la gloriosa Virgen ${ }^{280}$ María, madre suya, no permetrá nuestra buena e clara ${ }^{281}$ justicia peresca. E noresmenos, de todos vosotros tenemos tal $\mathrm{e}^{282} \tan$ firme ${ }^{283}$ confiança que faréys enta $^{284}$ nos, vuestro rey e senyor natural, aquello que vosotros e vuestros

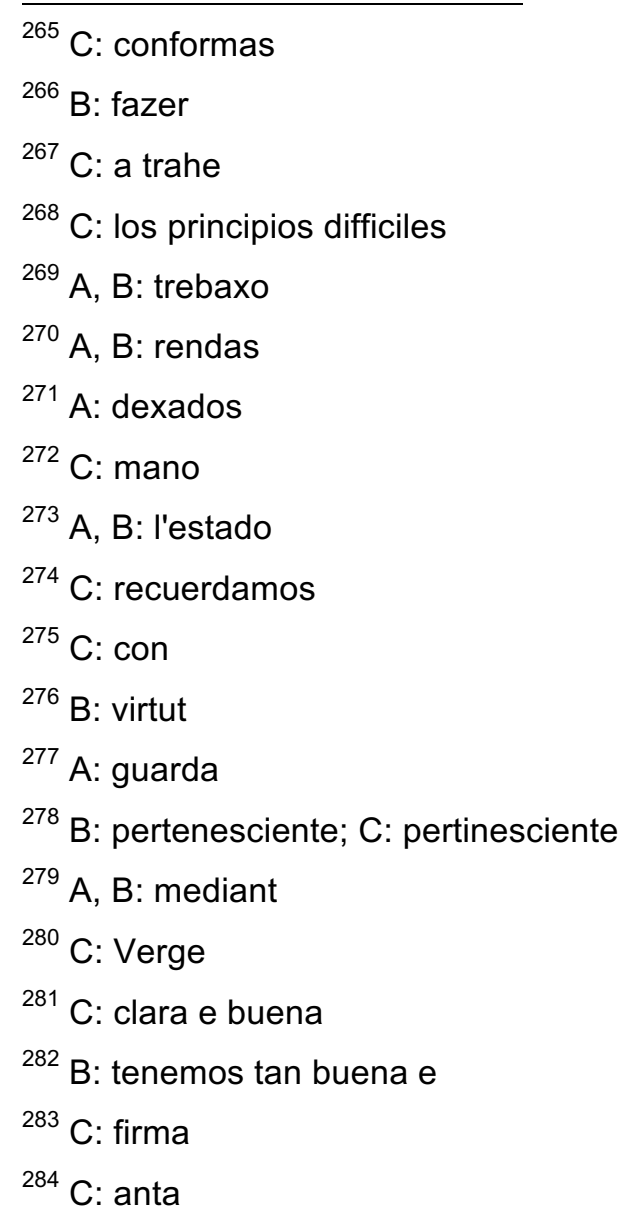


antecessores con acostunbrada fidelidat ${ }^{285}$ e virtut havéys acostunbrado fazer vers los otros reyes de gloriosa memoria e nos, de que se seguirá ${ }^{286}$ servicio gran $^{287}$ a nuestro senyor Dios, tranquilidat e reposo a la república de todos nuestros regnos e tierras, renombre e fama inmortal de todos vosotros.

\footnotetext{
${ }^{285}$ C: fidelitat

${ }^{286}$ A, B: siguira

${ }^{287}$ B: grant
} 